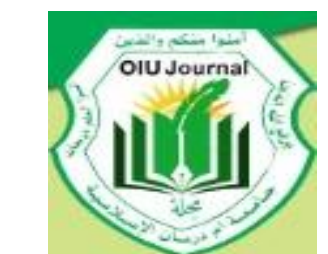

2014; $10(2): 1-49$
Omdurman Islamic University Journal(OIUJ)

مجلة جامعة أم درمان الكسلامية

https://journal.oiu.edu.sd/index.php/oiuj https://doi.org/ 10.52981/oiuj.v9i2.1618

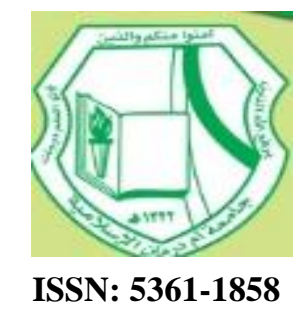

\title{
الفقه الإسلامي حقيقته و تجديده
}

" التوم محمد المشرف الزين

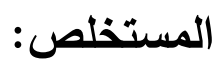

* ثبت للباحث أن هناللك تطورٌ في التعربف بالفقه من الناحية الاصطلاحية، وقد أصبح لفظ الققه أخيراً، بطلق على الفقه الإسلامي المدون في كتب الفقه.وقد تتاولت الورقة العلاقة بين الثربعة الإسلامية والفقه وأقسامه. ثم تتاولت الدراسة، بعد النشأة وتظور الفقه الإسلامي، مسألة تجديده فأبانت أن المقصود بالتجديد هو الاحتفاظ بالفقه وترميم ما بلي منه وإدخال التحسين عليه، ولولا هذا ما سمي تجديداً. وهناك أمورٌ كثيرة استحدثت في حياة الأمة، فهذه تحتاج إلى إعادة النظر فيما ثبت فيها من أحكامٍ قديمة على الخصوص فيما بسمي بفقه النوازل. 


\section{Abstract:}

It has been proved that there is a noticeable development in the term (fiqh) 'jurisprudence' through time. and then as a general term for all written works of jurisprudence.

The paper distinguishes between the terms 'shari'a' and 'fiqh' However, there is a close correlation between them, as 'fiqh' cannot be separated from 'shari'a'.

After elaborating on the evolution and development of 'fiqh' in Islam, the paper deals with the issue of modernization of 'fiqh'. It should be noted that modernization of 'fiqh' does not mean dumping the old version of 'fiqh' and replacing it with a 'modern' version. Rather, it means retaining the old 'fiqh', and updating the outdated areas in it.

On the other hand, many new issues which have emerged in our life requires reviewing the old provisions, especially what is known as the "fiqh 'jurisprudence' of emergencies". 
الفقه الإسلامي

حقيقته تجديده

الإف:

تهدف هذه الورقة إلى تباين معنى أو مفهوم الفقه الإسـامي بمعناه

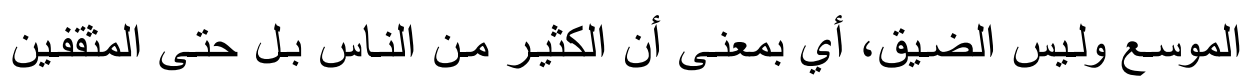

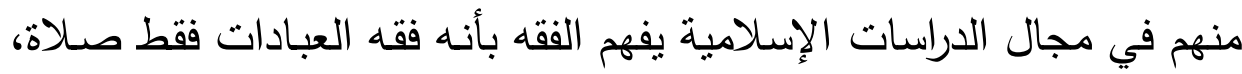
صيام، وزكاة، وحج لا أكثر من ذللك.

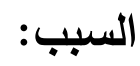

وكذلك هدفت إلى توضيح العلاقـة بـين الثـريعة الإسـالامية والفقـه الإسلامي، فبينت أن العلاقة بينهما وثثقة وبينهما ارتباط كبير فلا ينفك الفقه

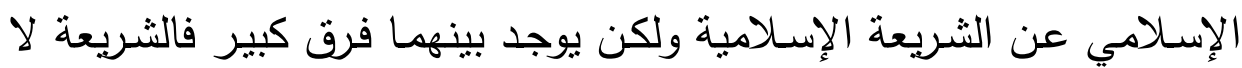
شك وحي رباني والفقه الإسلامي اجتهاد بشري لفهم هذه الثريعة، ثم تطبيقها في واقع حياة المسلمين عقيدة وعبادة، ومعاملات وسلوكيات وبتطبيقها تتال الأمة السعادة والفلاح في الدارين.

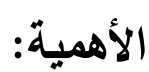

ثم هدفت إلى بيان مكانة فقهنا الإسـامي وميزته التي تميز بها عن سائر فقه وقوانين البشرية وكذلك تتاولت النشأة والتطور للفقه الإسلامي فتبين بأنه فقه قابل للتجدد والتطور وليس فقهاً جامداً. فثريعة سيدنا محمد صلى الله عليه وسلم شريعة صالحة لكل زمان ومكان. وهذا ما استفادة الإمام الثنافعي حين غير من منهجه وهو في العراق اله

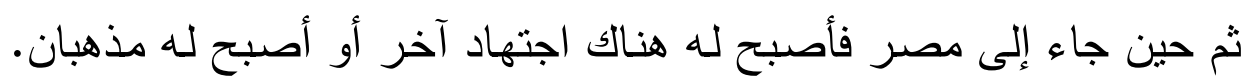
والله الموفق،، هـ 


\section{التعريف بالفقه الإسلامي لغة واصطلاحاً:}

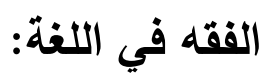

قال ابن منظور (فقه) العلم بالثيء والفهم له، وقال غيره والفقه في

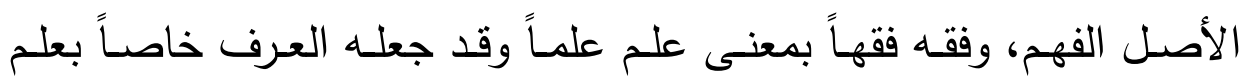

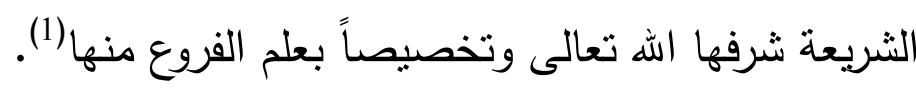

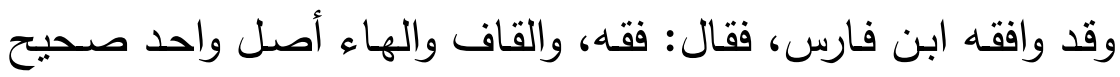

يدل على إدراك الثيء "أب فهمه" والعلم به، نقول فقهت الحديث أفقهه وكل

علم بشيء فهو فقه. (2)

وفرق الآمدي بين الفهم والعلم إذ قال الفقه في اللغة عبارة عن الفهم

وقيل: هو العلم والأثبه أن الفهم مغاير للعلم إذ الفهم عبارة عن جودة الذهن

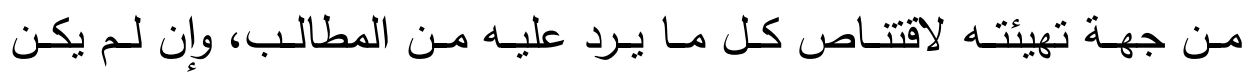

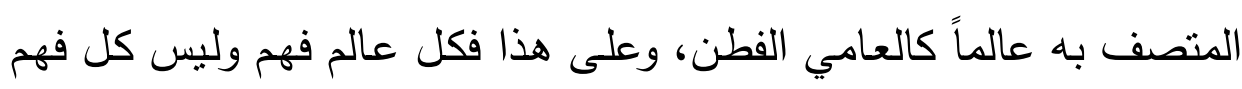

عالماً. (3)

ويقول أيضاً الراغب الأصفهاني في مفرداته "فقه" الفقه هو التوصل

إلى علم غائب بعلم شاهد فهو أخص من العلم والفقه العلم بأحكام الثريعة.

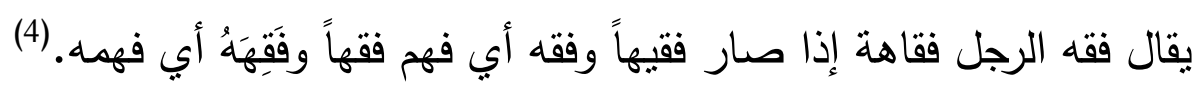
لذا نفهم أن كلمة الفقه في اللغة لا يخرج معناها من أمرين:

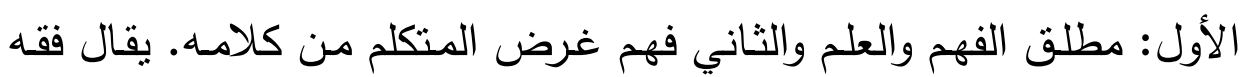

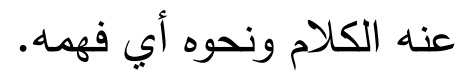

وهذا ما ذهب إليه أحد العلماء في تعريف الفقه لغة إذ قال هو فهم إنها

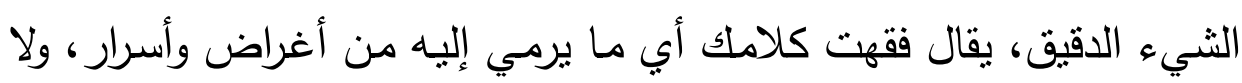
يقال فقهت السماء والأرض. (5) 
وفي مجال البحث عن مدلول كلمة الفقه في اللغة لا بد من التدليل عليها بما ورد في القرآن الكريم وسنة نبينا محمد صلى اله عليه وسلم. أولاً: القرآن: قال تعالى: (ما نفقه كثيراً مما تقول) سورة هود، الآيـة

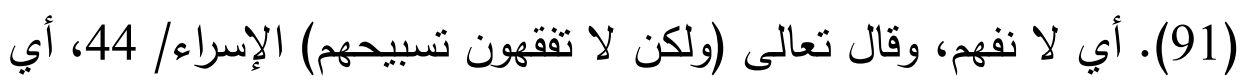

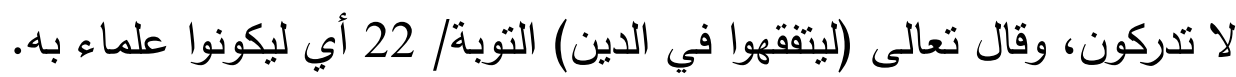

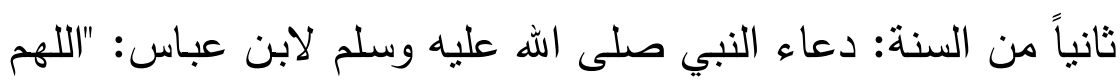

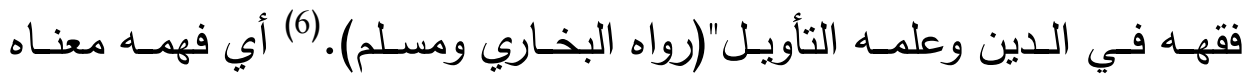
وتأويله. وقوله صلى الله عليه وسلم "من برد الله به خيراً يفقهه في الدين". * 2/ تعريف الققه اصطلاحاً:

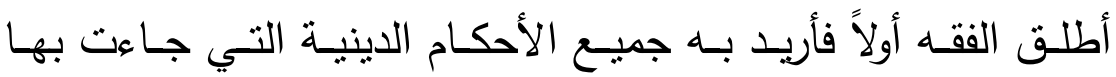

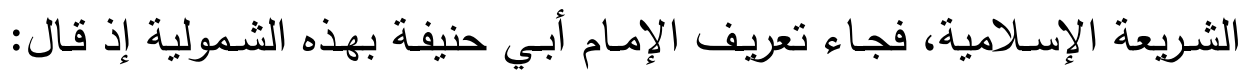

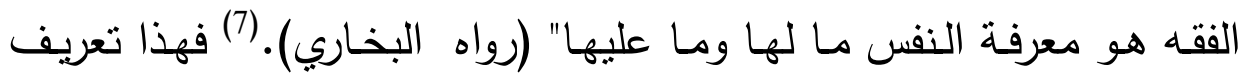

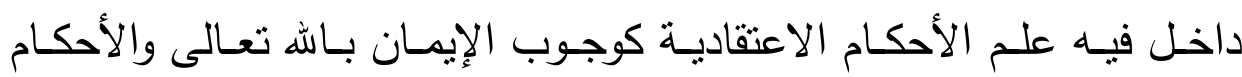

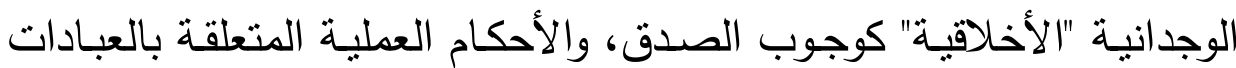
والمعاملات كوجوب الصلاة والصوم وإباحة البيع. (8) ثم طرأ تغيير على إطلاق لفظ الفقه بمعناه الاصطلاحي فصار يطلق

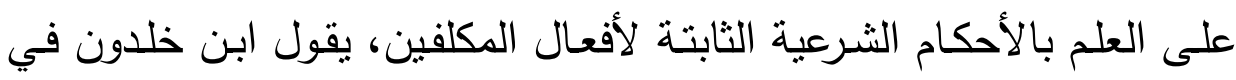

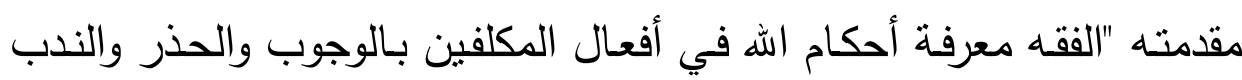
والكراهة والإباحة، وهي متلقاة من الكتاب والسنة وما نصبه الثنارع لمعرفتها من الأدلة، فإذا استخرجت الأحكام من تلك الأدلة قيل لها فهي فقه". (9) بهذا التعريف يكون الفقه هو العلم بالأحكام الثرعية، النظر والاجتهاد الادلهاد

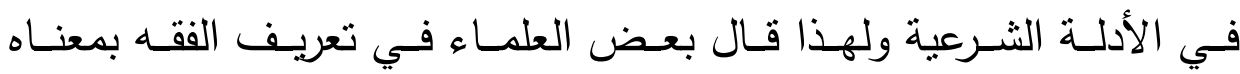


الاصطلاحي الثـامل، بأنـه "العلم بالأحكام الثـرعية العمليـة المكتسبة مـن

أدلتها التفصيلية بالاستدلال."(10)

كما أطلقوا كلمة الفقه على هذه الأحكام نفسها.(11) وهذا هو المراد في نحو قولك: درست الفقه الإسـلامي وهذا هو المعني الثاني للفقه. وعلى هذا

يعرف الفقه بأنه "مجموعة الأحكام العلمية المشروعة في الإسلام". (12)

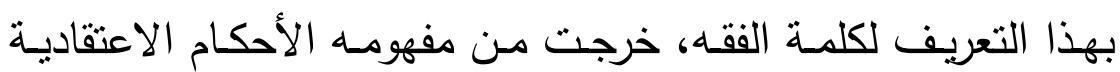

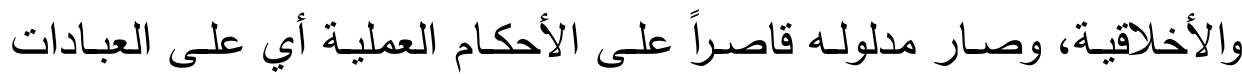

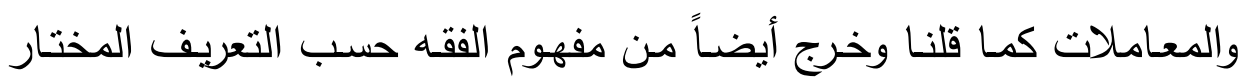
الأحكام التي لا تؤخذ بالاستـلال أي بطريق النظر في الأدلـة التفصيلية

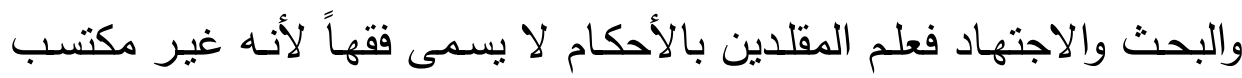
عن طريق النظر والاستدلال، كما لا يسمى صاحبها فقيهاً. (13) 3/ تعريف الققه بمعنى أعمق وأدق:

نجد الكثبرين من المتخصصين في الدراسـات الإسـامية يحصر فهمهـ

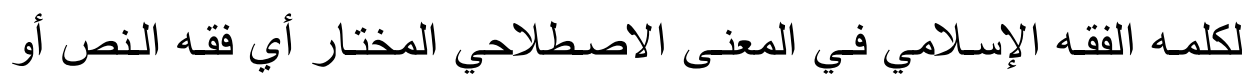

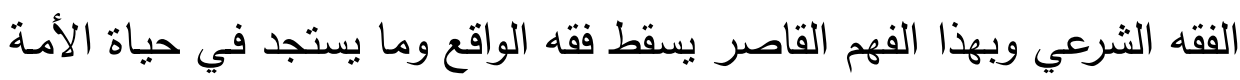
من قضايا كثيرة وغير المستجدة منها التي في حاجة لفقه عميق وأدق وفهم

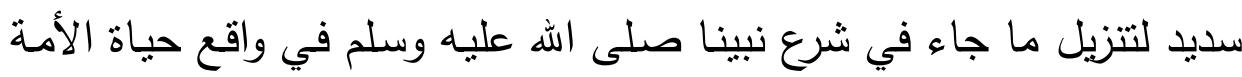

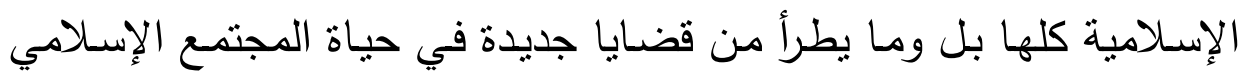
فالفقه ليس قاصراً على فقه النصوص الذي ذهب إليه أئعة الفقه وجعلوا أبواباً

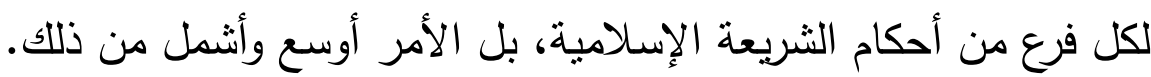

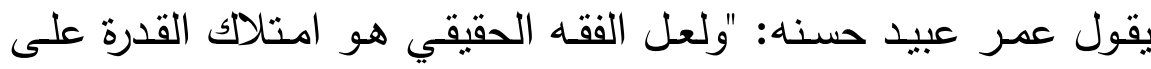
تحقيق المناط بالمصطلح، أو القدرة على تجريد النص من قيد الزمان والمكان 
والاجتهـاد فـي تنزيلـهـ على واقـع النـاس ومعالجتـهـ لمشـكلاتهم واستشـــافه

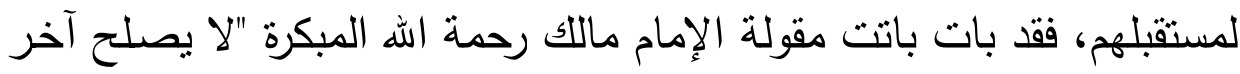

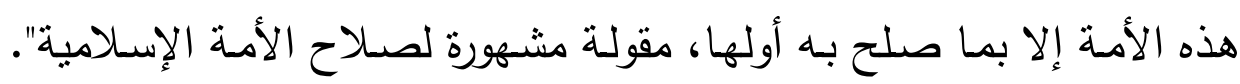

فليس الفقه الذي نقصده هنا هو حفظ كتاب وسرعة استخكار مسائل مع استمرار العجز عن نوليد مثال غير مثنال الأقدمين الذي مـا يزال يتداول وينقل من كتاب إلى آخر أو من درس إلى درس آخر وقد ئد يكون هذا متوفراً

للكثير من حملة الفقه اليوم".(15)

فالأمـة الإسـلامية اليوم في أنشد الحاجة إلى فقهـ جديد لحاجـة العصر

الآن ومتطلباته والنوازل التي حلت بالأمهة، في كل شأن من شئون، حياتها.

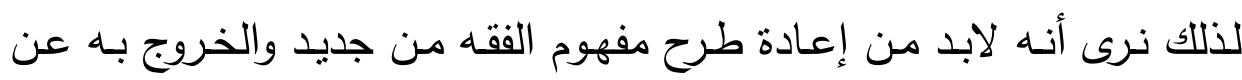

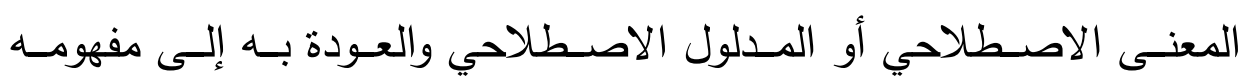

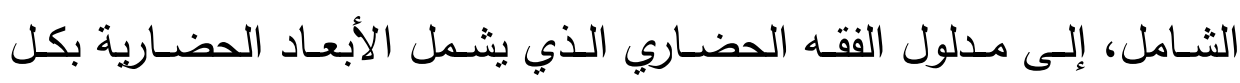

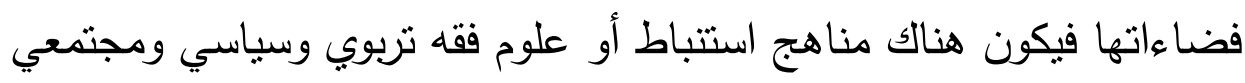

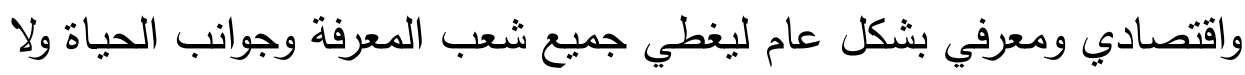
يقتصر على الجانب التشريعي فقط.

4/ علاقة الفقه بالشريعة الإسلامية:

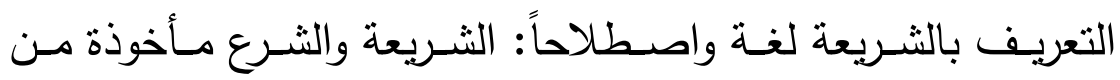

الثريعة وهي مورد الناس للاستقاء.(17)

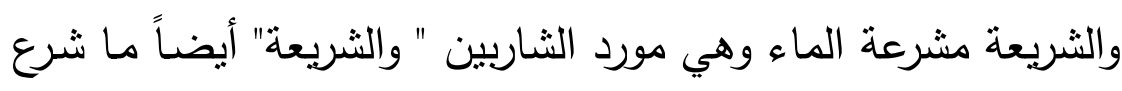
الله لعبادة من الدين وقد شرع لهم أي سن لهم". (18) 
والثشرعة والثـريعة في كـلام العرب بمعنى مشـرع المـاء وهي مورد

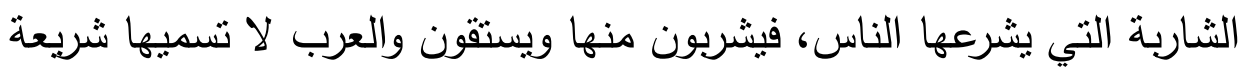

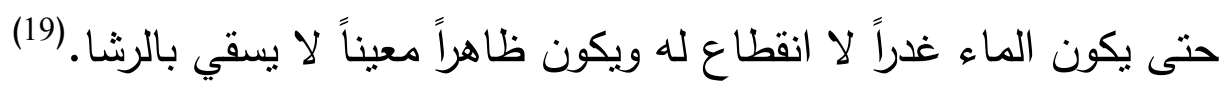
فالعرب تستعمل الثريعة في الطريقة المستقيمة. قال الهروي قال ابن عرفة: الثرعة والثريعة سواء وهو الظاهر المستقيم من المذهب شرع اله هذا جعله مذهباً. (20)

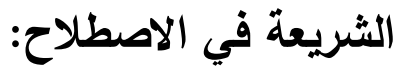
مـا شرع اله لعباده من الدين أي من الأحكام المختلفة. (21) وسميث

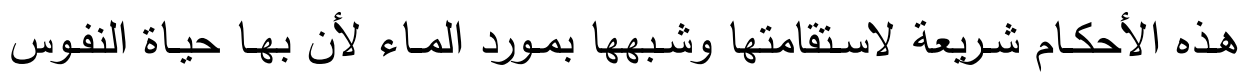

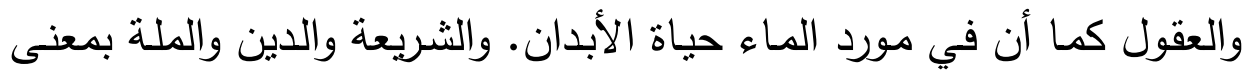

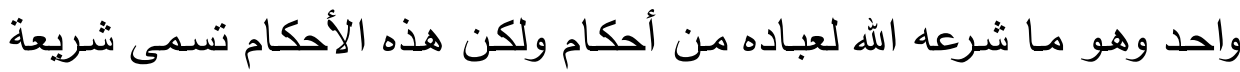

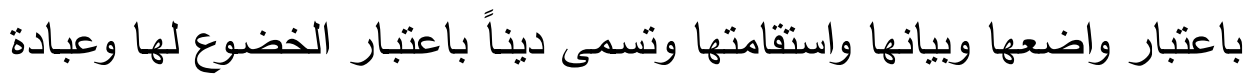
الله بها وتسمى ملة باعتبار إملائها على الناس. الفرق بين الثريعة والفقه:

مـن المهـ جـاً التمييز بـين قولنـا الثـريعة الإسـلامية وقولنـا الفقـهـ الإسلامي فالثريعة هي نصوص القرآن الموحى به من الله إلى رسوله محمد

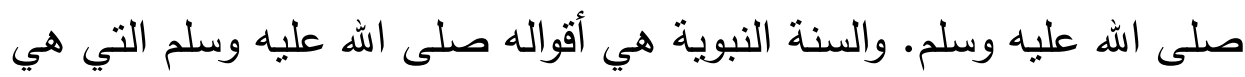

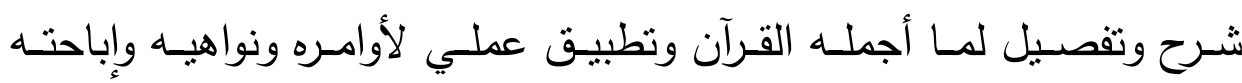
باعتبار أن كل ما يصدر عن الرسول صلى اله عليه وسلم منصـاً بتطبيق الثريعة وتفسيرها ليس من عند نفسه ومن رأيه الثخصي وإنما هو بوحي من لن الثن 
أما الفقه فهو ما يفهمهـ العلماء من نصوص الثريعة وما يستتبطونه

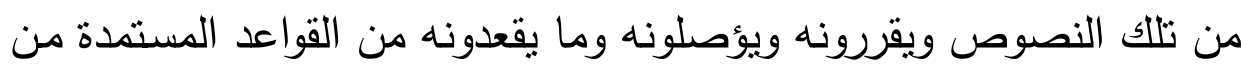
دلالات النصوص. (23)

قلنـا إن الثـريعة الإسـلامية تشـتمل على جميـع الأحكـام الثـرعية

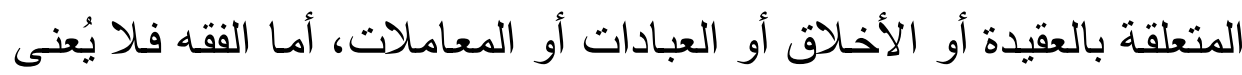

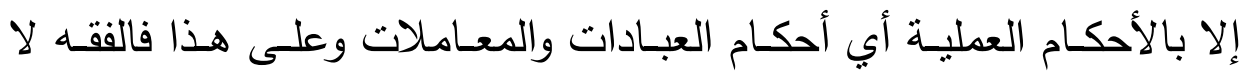
يشتمل إلا على الأحكام العملية ومن ثم فالثربعة أعم وأكثر شمولاً؛ لأنها

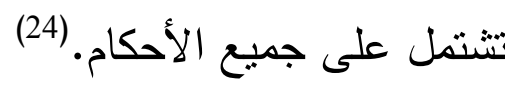

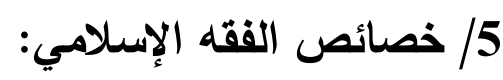

الفقه: هو الجانب العملي من الثريعة والثريعة كل ما شرع الله لعباده من

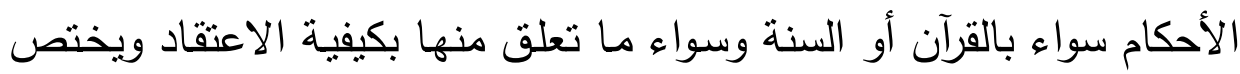

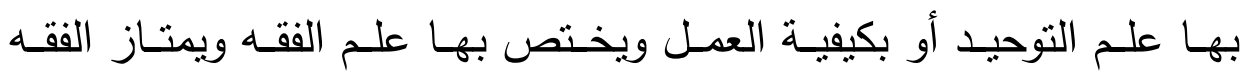

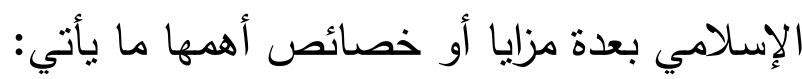

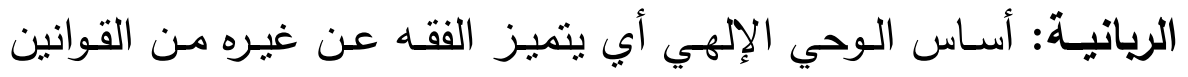

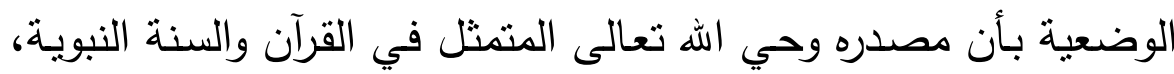

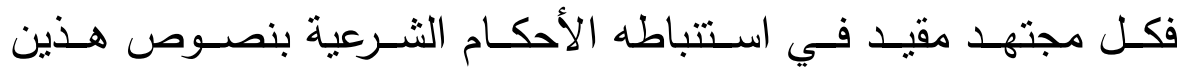

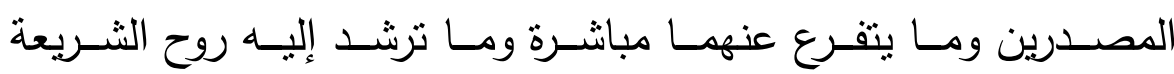

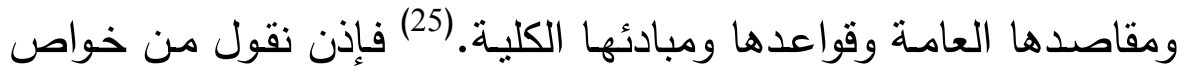
الققه الإسلامي الربانية. الشــولية والإحاطة : وتميز الفقه بخصوصية أخرى هي شـوله لكل جوانب الحياة روحية ومادية، فردية واجتماعية، دينية وسياسية فلا يدع 
ناحية منها إلا شرع لها وحكم فيها، من أدب المائدة (الأكل والثرب) إلى بناء الدولة وسياسة الحكم، وسياسة المال. (26)

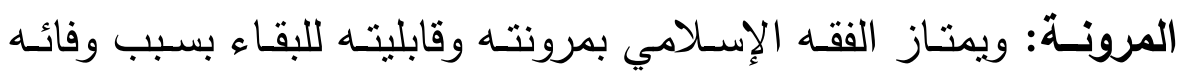
بحاجـات الناس ومصـالحهم المشروعة. وهذه الخصيصـة بالحقيقة دليل

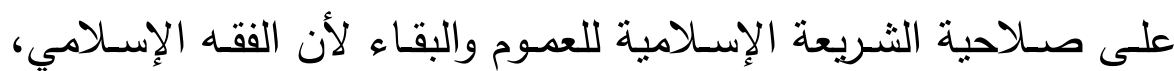

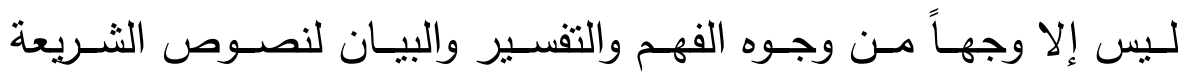
وأحكامها وتطبيقـاً لمبادئهـا وقواعدها على وجلى جزئيـات الوقـائع والأحـداث حسب الأزمنة والأمكنة ومصالح الناس.(27)

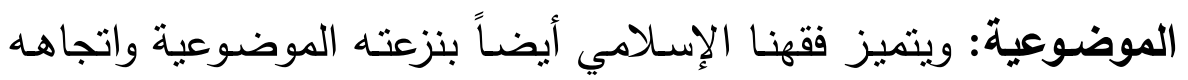

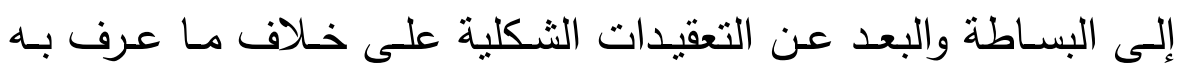
القانون الروماني من نزعة ذاتية واتجاه إلى الثكلية. (28)

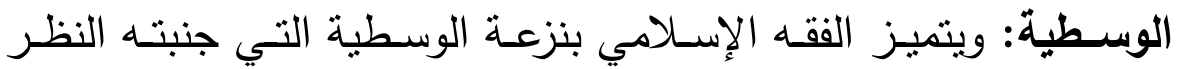

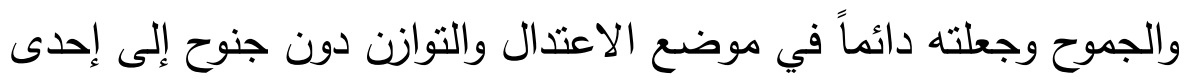
جهتي الإفراط أو التفريط وهذا أثر من آثار صفته الربانية فقلمـا يسلم تفكير البشر من الغلو أو التقصير نتيجة التأثر بالمؤثرات البيئية والزمنية التي تدفع الإنسان إلى مواجهة التطرف عادة بتطرف مثله أو أثند. (29)

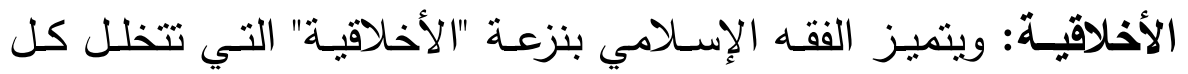
أحكامه، من عبادات ومعاملات وعقوبات وأحوال شخصبة وشؤون دولية

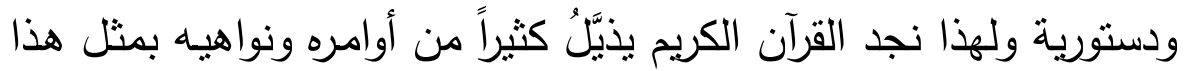

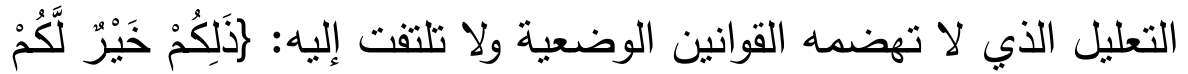

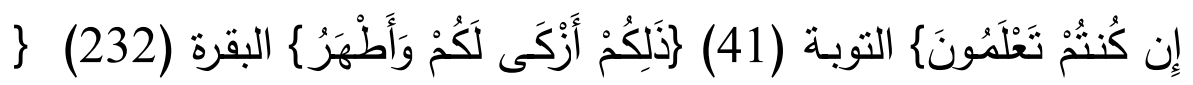




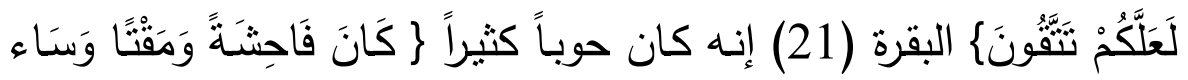
سَبِيلاًُ النساء (22). فالقوانين الوضعية لا يهمها الزكاة والطهر والتقوى، إنما يهمها قبل كل

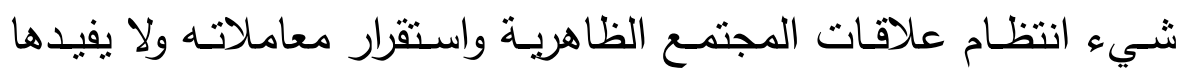
كثيراً الأمر - على حساب الطهر والتقوى.(30) 6 أقسام الأحكام الفقهية:

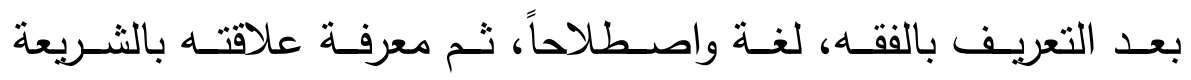
الإسلامية وكذلك خصائصه، يأتي البحث عن تقسيمه إلى الأحكام الآتية(31):

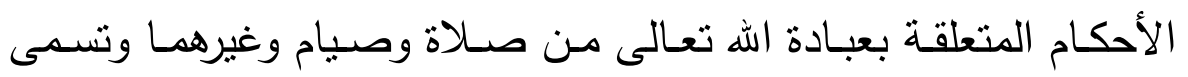

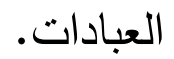

الأحكـام المتعلقـة بالأسـرة مـن نكـاح وطـلاق ونسـب ونفقـة ووصـايا وميراث... الخ. وتسمى بلغة اليوم الأحوال الثخصية.

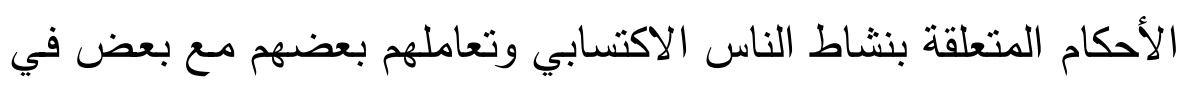

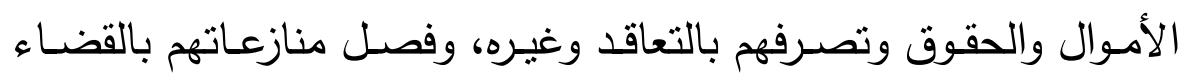

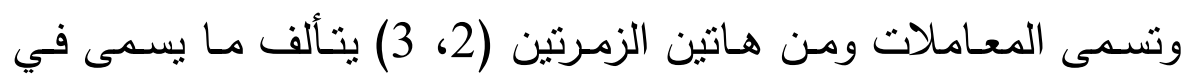
الاصطلاح القانوني الحديث (القانون المدني).

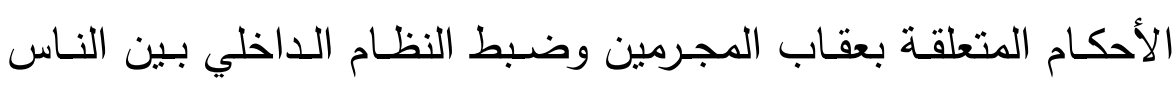
وتنسى العقوبات. • الأحكام المتعلقة بالأخلاق والحشمة والمحاسن والمساوئ وتسمى الآداب.

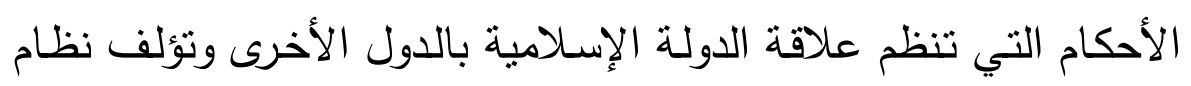

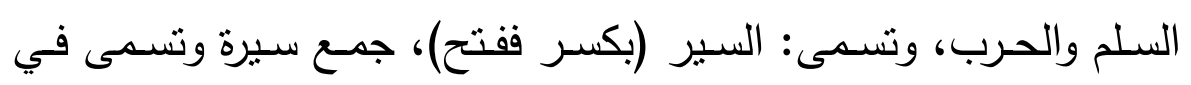
الاصطلاح القانوني "الحقوق الدولية العامة". 
الأحكـام المتعلقـة بسـلطان الحـاكم على الرعيـة، وبـالحقوق والواجبـات

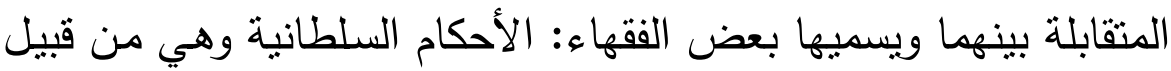
ما يسمى السياسة الثرعية.

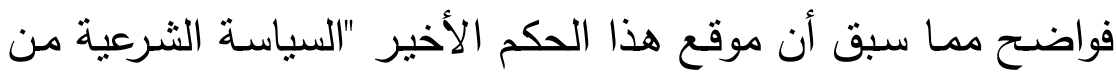

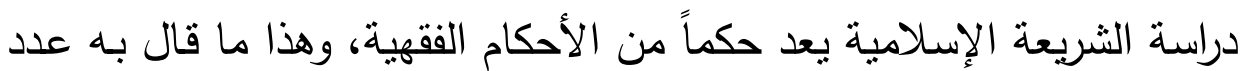

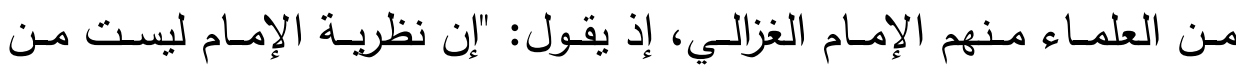

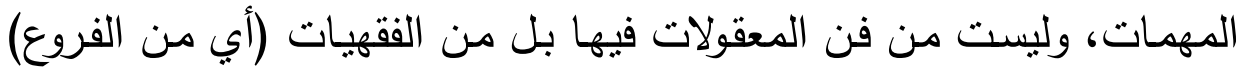

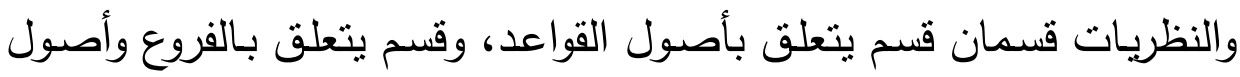

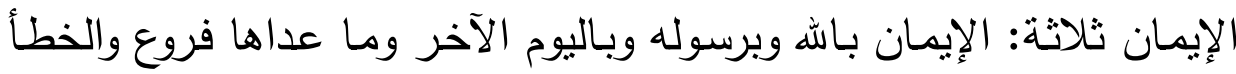

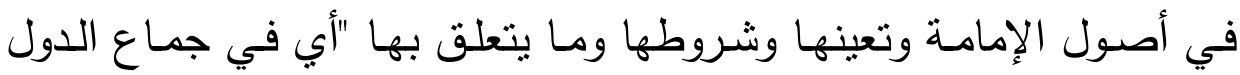
والسياسيين" لا يوجب شيء منه التكفير . (32) 7/ وإمـام الحرمين الجويني (419- 478هـ) (1028- 1085) يقول: "إن الكلام في الإمامة ليس من أصول الاعنقاد".(33)

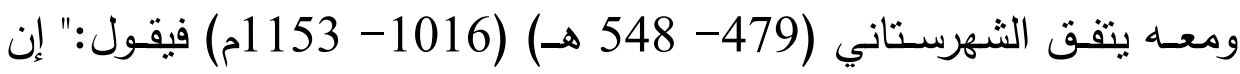

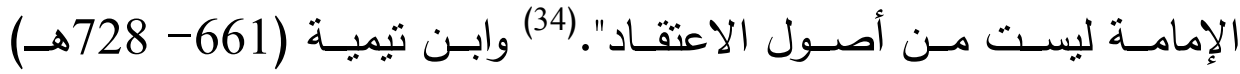
(1263- 1328م) يقـول عـن "الإمامـة" "أنهـا ليسـت مـن أركـان الإنسـلام

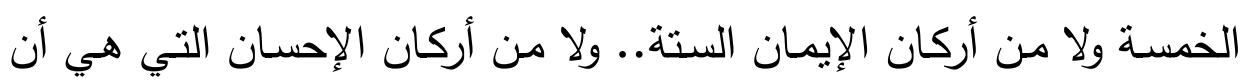
تعبد اله كأنك تراه فإن لم تكن تراه فإنه يراك".(35)

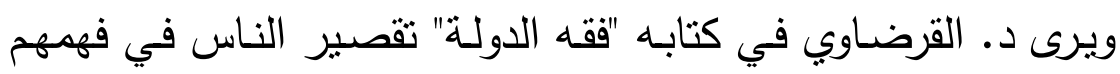
لققه الدولة فيقول: "وهو فقه قصر فيه المسلمون كثيراً في الأزمنة الأخيرة ولم

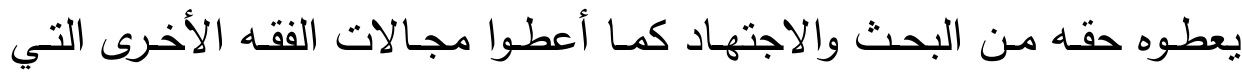

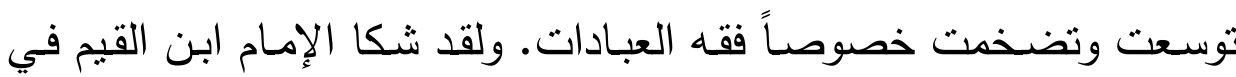


عصره "القرن الثامن الهجري" من جمود فقهاء زمانه حتى إنهم اضطروا أمراء

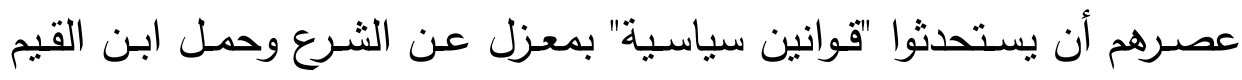
الفقهاء الجامدين تبعة انحراف الأمراء والحكام وشرودهم عن منهج الثريعة بـرنة

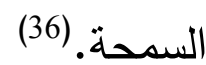

ويقول محمد سعيد العوا "تتاولنا في عدد من الفصول السابقة بعض المسائل التي تبرز فيها حاجتتا إلى فقه جديد في المجال السياسي والباحثّن

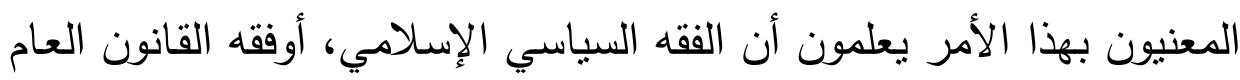

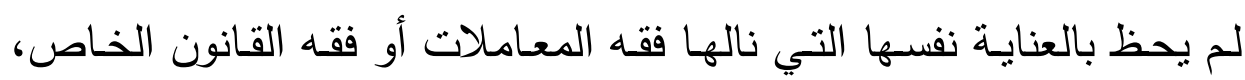

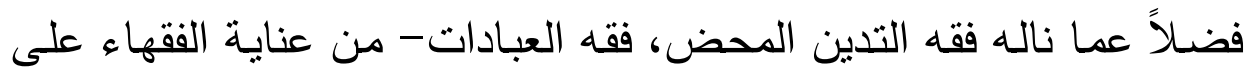
مر التأريخ.

إن الأمــة الإسـلامية ليسـت أمسة سـائبة بـل هـي أمسـة ملتزمـة بعقيدة

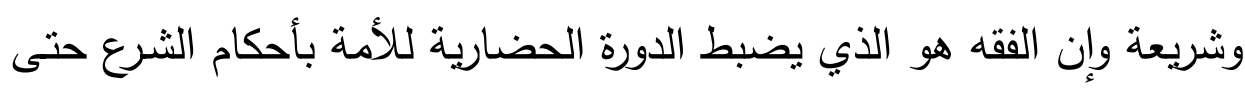

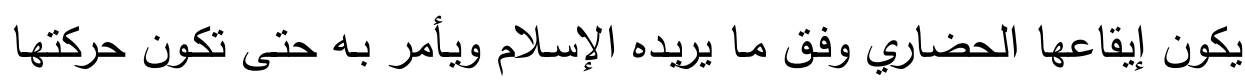

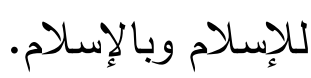
وليس الفقه - إذن - خاصاً بالأحكام الفرديـة والأسرية بل هو يشمل الحياة الاجتماعية والسياسية والدستورية والمالية والدولية وسائر مجالات الحياة. (38)

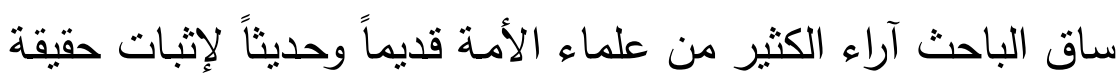

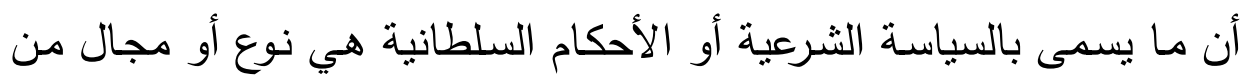

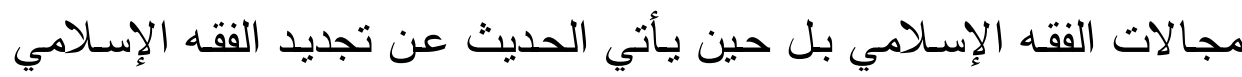
سيكون إن شاء الله هناك المزيد من إثبات الحقيقة الفقهية للسياسة الثرعية. 
8/ منزلة الفقه الإسلامي وأهميته:

إن للفقه الإنسلامي منزلـة عظيمة، لا تحد ولا تحصى بعددٍ كمـا لـه

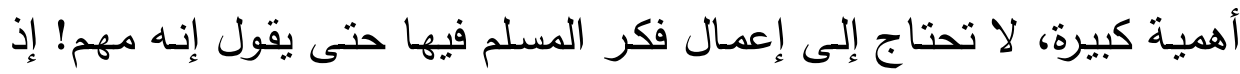

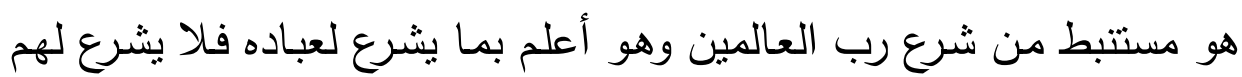
إلا ما ينفعه ولا بضرهم.

"اعلم أن الفقه الإسلامي جامعة ورابطة للأمسة الإسـامية وهو حياتها

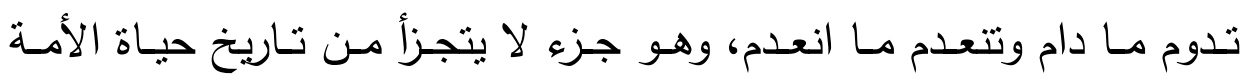

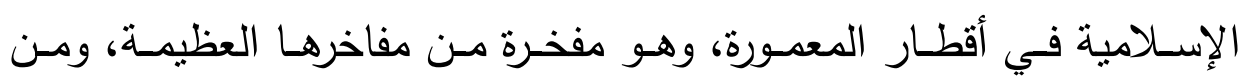
خصائصها لم يكن مثله لأي أمة قبلها". (39)

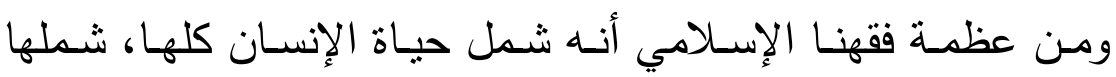
عقيدة وعبادات ومعاملات، سياسة واقتصاداً واجنماعاً ونحو ذلك.

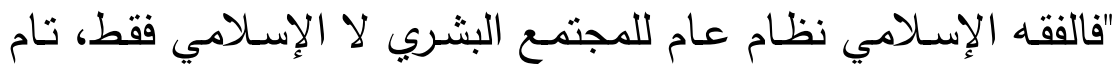

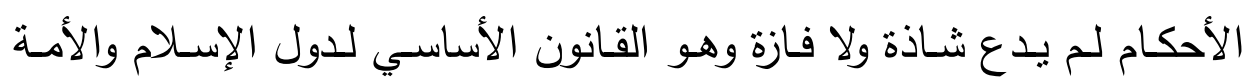

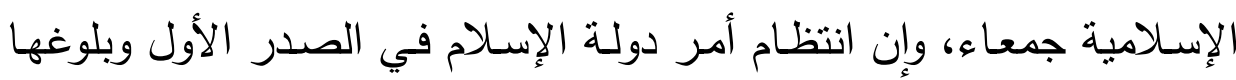

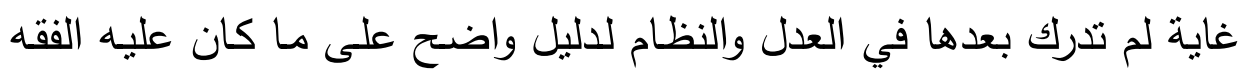
من الانتظام وصراحة النصوص وصيانة الحقوق ونزاهة القائمين بتتفيذ أوامره

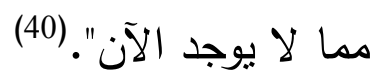
فالفقهـ الإسـامي مس مفاخر الأمـة الإسـلامية كيف لا وهو مؤسس

على روح العدل والمساواة واحترام الحقوق الخاصة والعامة والنظام. (41)

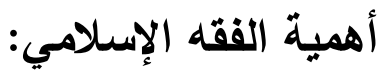
"بوضـح أهمية الفقه الحكيم الترمذي فيقول: "إن الذي يؤمر بالثنيء

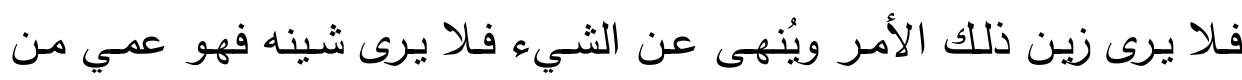


أمره.. ثم يقول فمن فقه أسباب هذه الأمور التي هي أمر ونهي بماذا أمر

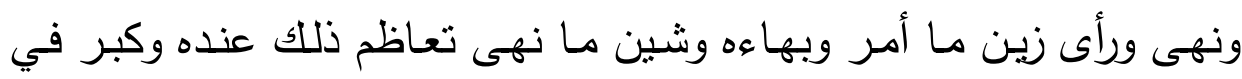

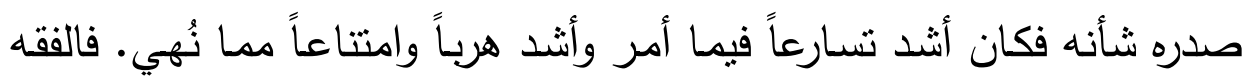

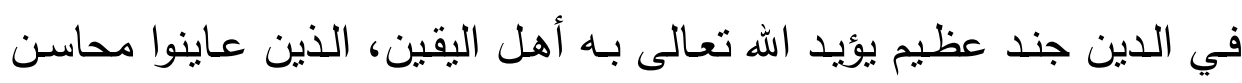
الأمور ومثاينها ومقدار الأثياء وحسن تدبير الله عز وجل لهم من ذلائك بنور يقينهم ليعدوه على يسر ومن حُرم ذلك عبده على مكابدة وعسر ؛ لأن القلب التباء

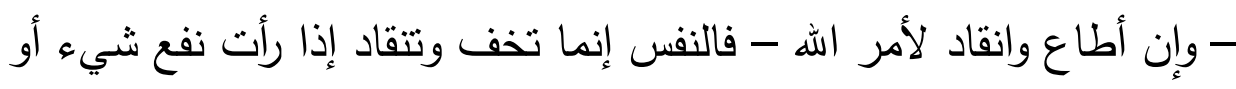

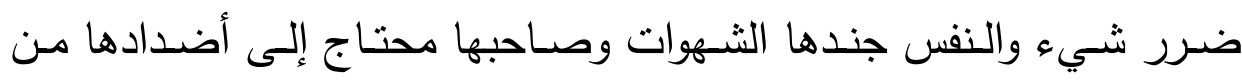
الجنود حتى يقهرها، وهي الفقه". (422) 9/9/ مصادر الفقه الإسلامي:

سبق أن تم تعريف الفقه في هذه الورقة بأنه أحكام شرعية عملية، أي الي

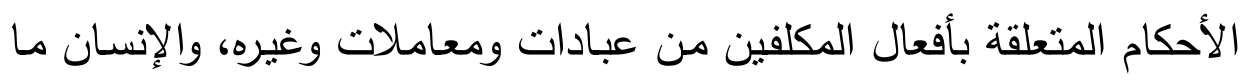

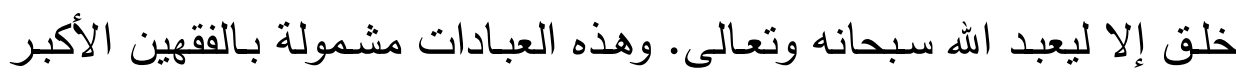

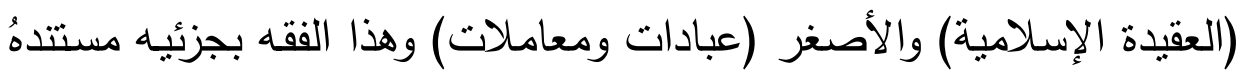
كتاب الله وسنة رسوله محمد صلى الله عليه وسلم والدقصود بمصادر الفقه الآله أدلته التي يُستقى منها. (43) ومن هنـا عد العلمـاء مصادر الفقه، أي منابعـه التي يُستنقى منها

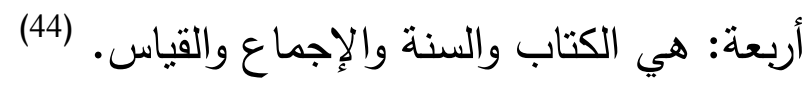
هذه مصادر الفقه الإسـلامي التي اجتمعت عليها كلمة العلماء ثم

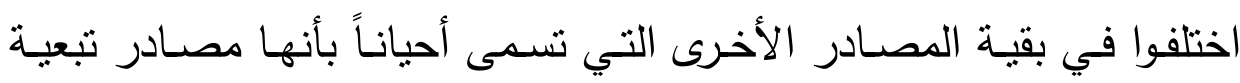
وأخرى تسمى ثابتة. 


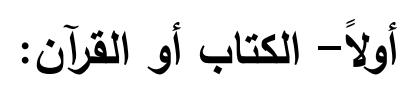

الكتاب، أو القرآن هو كتاب اله المنزل على رسوله محمد صلى الله عليه وسلم المكتوب في المصاحف، المنقول إلينا عن النبي صلى اله عليه

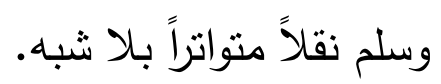

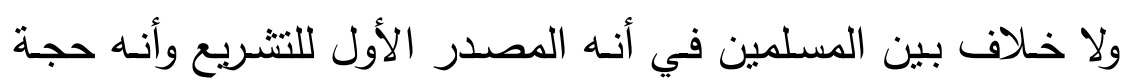

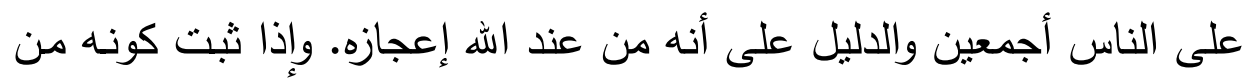

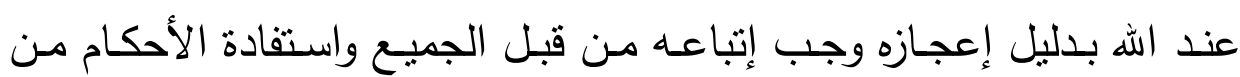

نصوصه. (45)

وهذا القرآن له أحكام متعددة، فجملة إما أن تكون هذه الأحكام أوامر

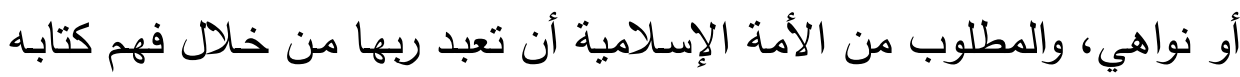
وتطبيقه في واقع حياتها.

$$
\text { وهي لا تخرج عن الأحكام التالية(46): }
$$

أحكام تتعلق بالعقيدة كالإيمـان بـالله واليوم الآخر وهذه هي الأحكام

$$
\text { الاعنقادية. }
$$

أحكام تتعلق بتزكية النفوس وتهذيبها وبيـان الأخلاق القويمـة الواجب

$$
\text { التحلي بها والأخلاق الرديئة الواجب التخلي عنها. }
$$

$$
\text { وهذه هي الأحكام الأخلاقية. }
$$

الأحكام الدتعلقة بأقوال الدكلفين وأفعالهم فيما عدا النوعين السابقين وهذه

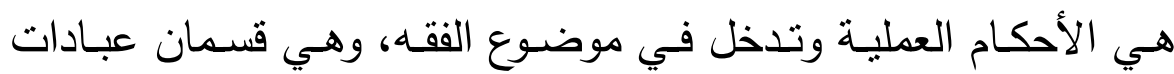

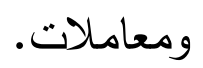

وقد جاء بيان هذه الأحكام في القرآن الكريم إمـا كلياً أي بذكر القواعد

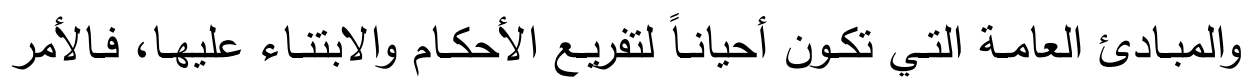


بالثورى والعدل والحكم أو إجمالياً أي ذكر الأحكام بصورة مجملة تحتاج إلى الى إلى

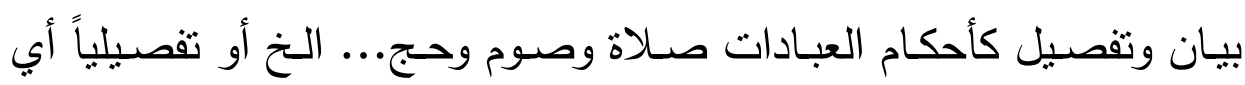

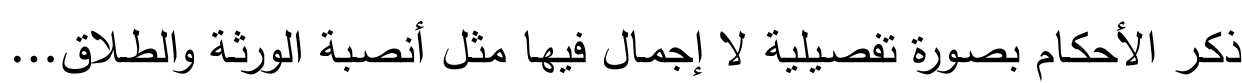

\section{0/ المصدر الثاني "السنة":}

يطلق لفظ السنة على ما جاء منقولاً عن الرسول صلى الله عليه وسلم من قول أو فعل أو تقرير ، وهي بهذا المعنى مرادفة للفظ الحديث.

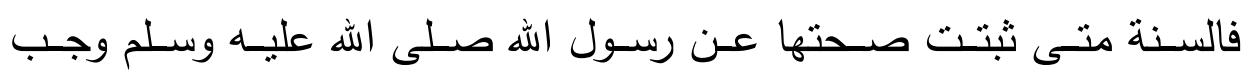

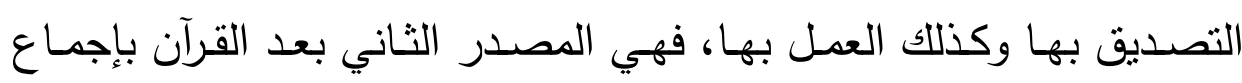

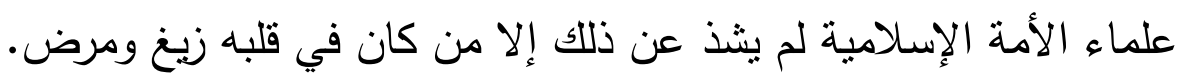

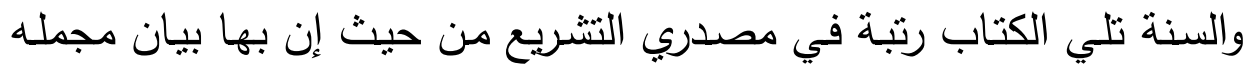
وإيضاح مشكلهِ وتقييد مطلقه وتدارك ما لم يذكر فيه.

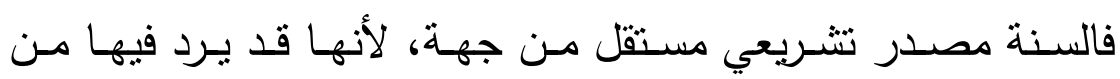
الأحكام ما لم برد في القرآن، كميراث الجدة، فقد ثبت أن النبي صلى اله له

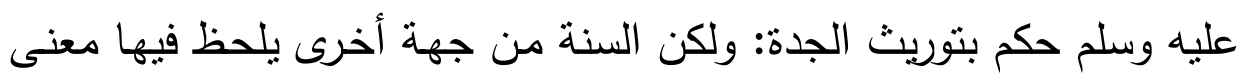

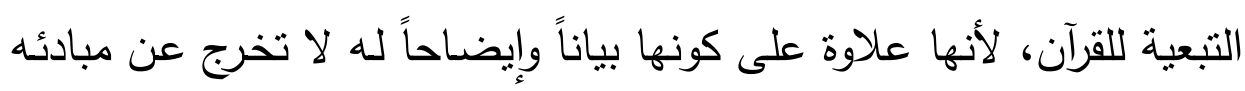

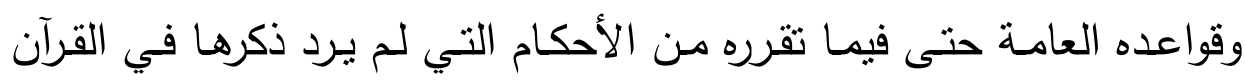

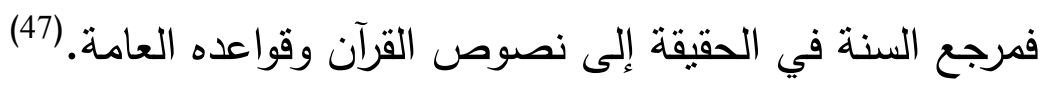

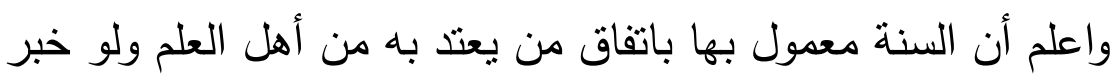

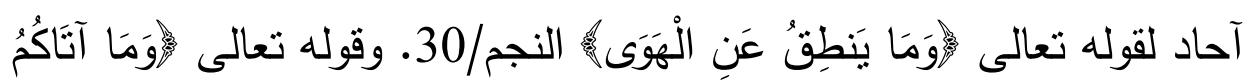

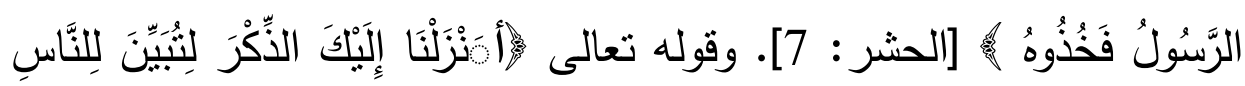

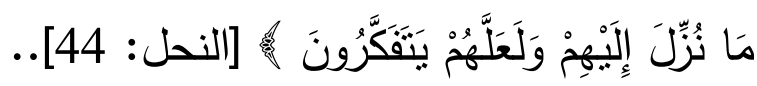


فالسنة تبين مـا أجمل في القرآن؛ لأن الثـريعة كانت تتزل تدريجاً

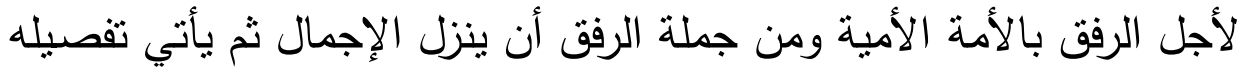

وكل ذلك موجود في السنة مبين فيها.(48) وأحاديث الأحكام كثيرة وردت في كل الأنواع التي ورد فيها القرآن فبينت مجمله وقيدت مفصله وزادت أنشياء كثبرة لم بذكرها القرآن وقد عني العلماء قديماً بجمعها ورتبوها حسب الترتيب الفقهي. هذان الأصـلان - الكتاب والسـنة - هما مصدرا التشـريع في عهد النبي صلى الله عليه وسـلم ومـن ذلك يتبين أن أسـاس القانون الإسـلامي

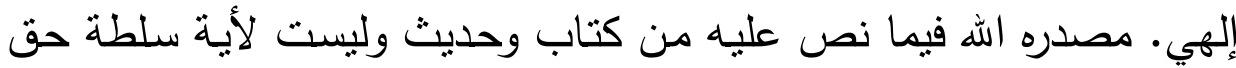
في مخالفتها، ولا الخروج على ما ورد في نصوصها، إنما يجتهد المجتهدون فيما لم يرد فيه نص مسترشدين بما ورد في الكتاب والسنة من قواعد كلية وبذلك تخالف القوانين الوضعية، ففيها تكون السلطة التشريعية في منتهى الحرية، في تعديل قانون أو إلغائه أو تفسيره، وليس الثأن كذللك في القوانين الإلهيـة فحريـة الفقهاء محدودة في دائرة فهم نصـوص القرآن ومقدار الثقة بالحديث وعدمها لم برد فيه كتاب ولا سنة صحيحة. (49) 11 / المصدر الثالث "الإجماع": بعد القرآن الكريم والسنة النبوية، وهما المصدران المتلازمان لتتريعنا

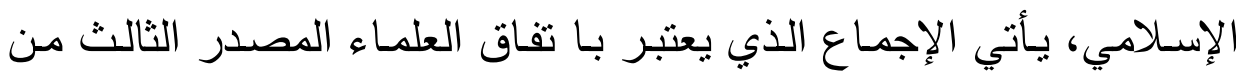
مصادر التشريع الإسلامي.

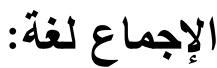
عرف بأنـه العزم، يقال أجمـع فـلان على كذا، إذا عزم عليـه وقد يتعدى بدون حرف الجر، فيقال أجمع فلان على كذا بمعنى عزم ومنه قوله 


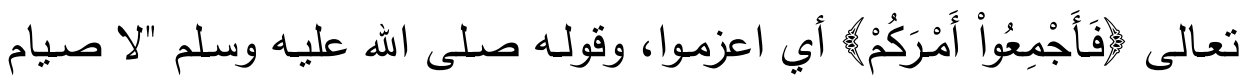

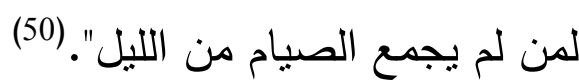
ويأتي بمعنى الاتفاق، يقال أجمع القوم على كذا أي اتفقوا عليه. وأما

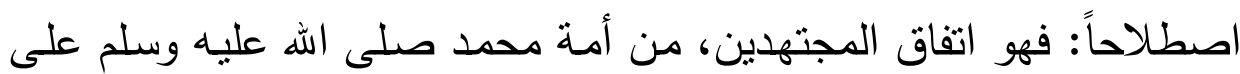
أمر من الأمور في عصر غير عصر الرسول صلى الله عليه وسلم. (51) والإجماع حجة قوية في إثبات الأحكام الفقهية ومصدر يلي السنة في الرتبة.

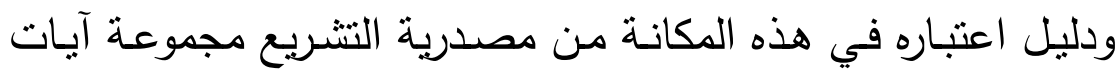
وأحاديث تدل على اعتبار إجماع الكلمة من أهل العلم والرأي.

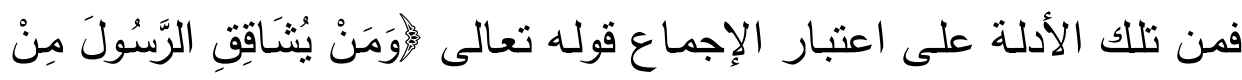

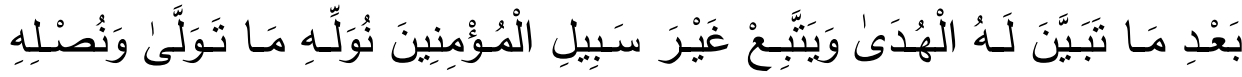

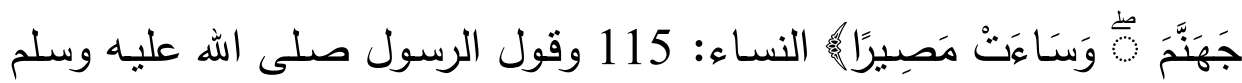

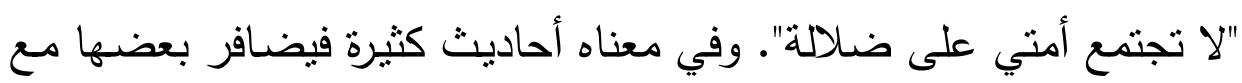
بعض ومع الآيات القرآنية وعدم الانثقاق عنها تئلف دليلاً كافياً في حجية

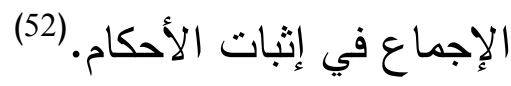
والإجماع مصدر للتشريع ودليل من أدلة الأحكام وقد ثبت ذلك الكا بنصوص كثيرة من الكتاب والسنة تعرف في مضامينها من كتب أصول الفقه.

الإجماع مصدر فقهي مشهود لله بالصحة والاعتبار فيمكن الاستفادة

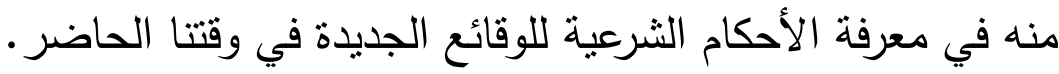
ومذهب الجمهور أن الإجماع حجة في الدين متعبد به ثبتت بـه الأحكام كما

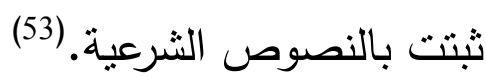


12/ المصدر الرابع "القياس": القياس في اللغة مصدر لقاس بمعنى قدر، يقال قست الأرض بالقصبة أي قدرتها بها وقست الثوب بالذراع أي قدرتـه بـه. (54) وعرف أيضـاً بالتقدير والمساواة. (55)

تعريفه في الاصطلاح: هو إلحاق واقعة لا نص على حكمها بواقعة ورد نص

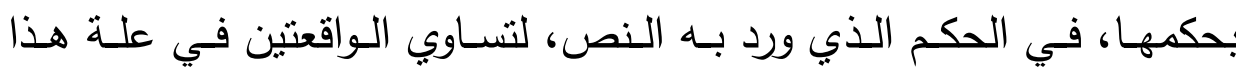

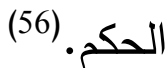
القياس هو المصدر الرابع من مصـادر التشريع المتفق عليها بعد كتاب اله وسنة رسوله الله صلى الله عليه وسلم، والإجماع والعمل بـه من ضن ضـرورات

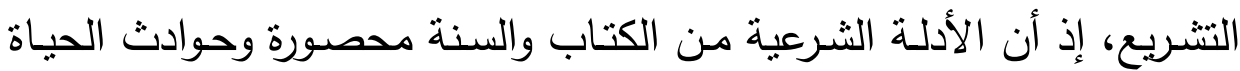
غير محصورة، فالنصوص الثرعية قاصرة عنها، ولا تفي بها فكان لابد من مصادر أخرى يلجأ إلبها المجتهدون في استتباطهم للأحكام، ولذلك جعل الله القياس هو الدصدر الذي نسد به الحاجة وتستوفي به الأحكام.(57)

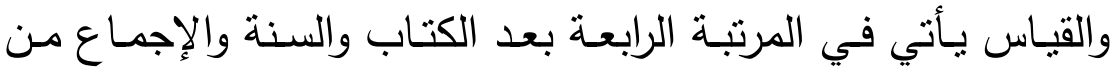
حيث حجيته في إثبات الأحكام الفقهية ولكنه أعظم أثراً من الإجماع في كثرة لركابه ما يرجع إليه من أحكام الفقه؛ لأن مسائل الإجماع محصورة ولم يأت فيها لهاعيا

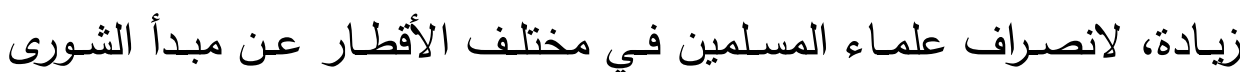

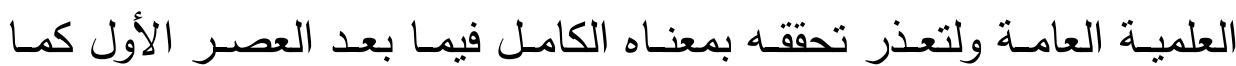
أوضحناه. أما القياس فلا يشترط فيه اتفاق كلمة العلماء بل كل مجتهد يقيس بهاه

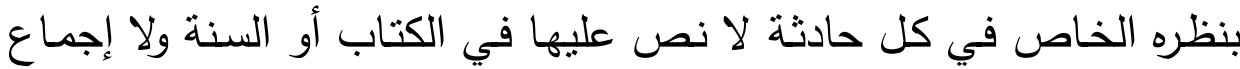


وبالجملـة نعلـم قطعـاً ويقينـاً أن الحـوادث والوقـائع فـي العبـادات

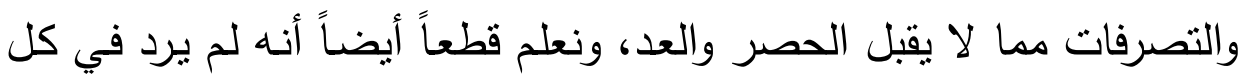

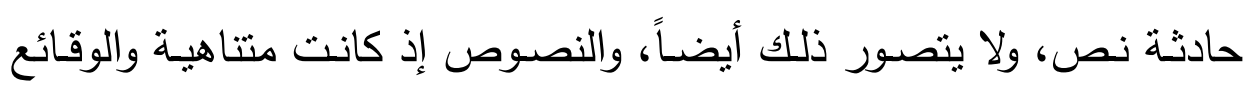
غير متتاهية وما لا يتتاهى لا يضبطه ما يتتاهى.. علم قطعاً: أن الاجتهاد

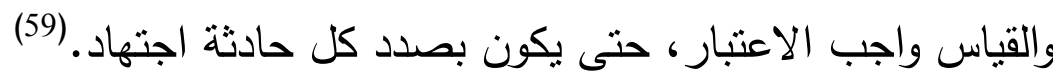
13/ المصادر المختلف فيها:

ونعني بها المصـادر التتـريعية الإجمالية، التي اختلف فيها الأئمـة

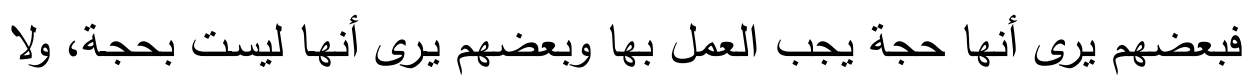

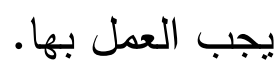

وهذا بخـلاف المصـادر المتفق عليها التي ذكرناهـا في الصفحات الماضية. وهي الكتاب والسنة والإجماع والقياس، وإنما كان متفقاً عليها لقيام الدليل القاطع على وجوب العمل بها.

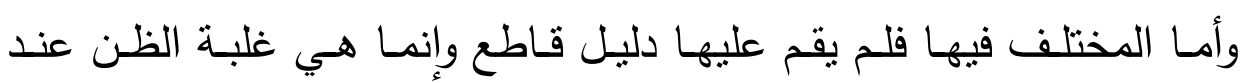
المجتهد. (60) ويقـول مصـطفى الزرقـا "إن هنـاك مسـتـدات أخـرى شـرعية لإثبـات

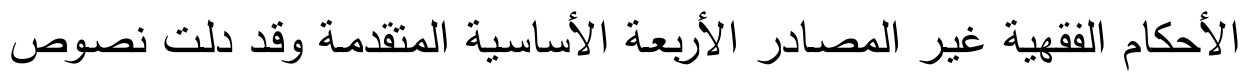
الكتاب والسنة على اعنبارها مستتداً صحيحاً لإثبات الأحكام.

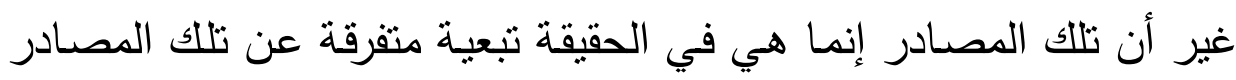

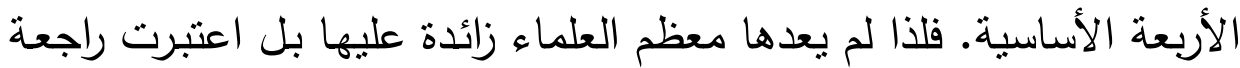
إلبها. (61) ومـن أهـم هـذه المصـادر التبعيـة: الاستحسـان والعـرف والمصـالح المرسلة وهنالك مصادر أخرى لمصادر الفقه الإسلامي. 
الاستحسان:

في اللغة عد الثيء حسناً، وفي اصطلاح العلماء هو العدول عن قياس جلي

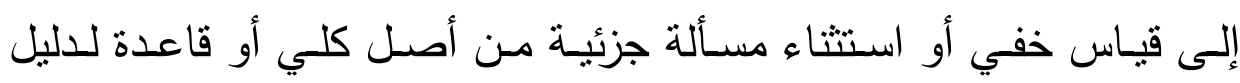
يقتضي هذا العدول.

العرف: ما اعتاده الناس وساروا عليه في أمور حياتهم ومعاملاتهم من قول

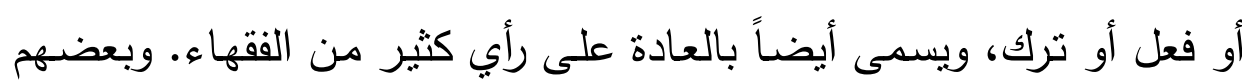

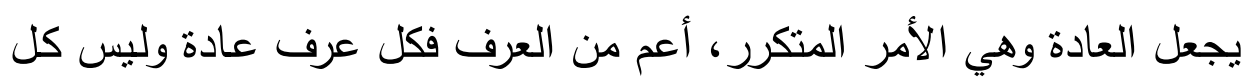

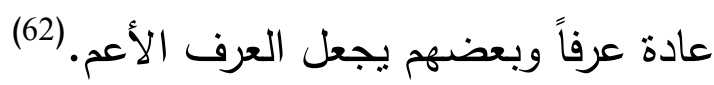

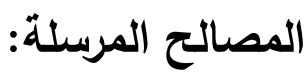

المصلحة المرسلة أي المطلقة، وفي اصطلاح الأصوليين: المصلحة

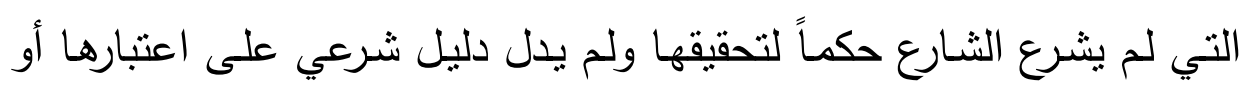
إلغائها وسميث مطلقة؛ لأنها لم تقيد بدليل اعتبار أو دليل إلغاء. (63)

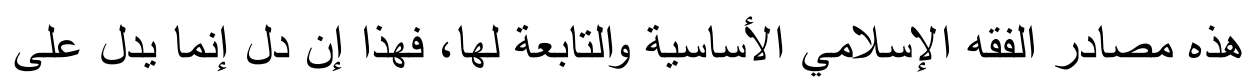

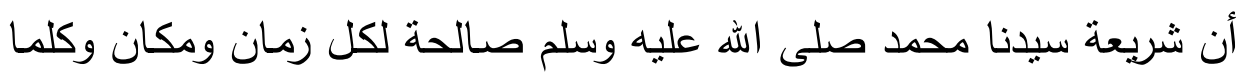
طرأت مشكلة يوجد حل لها.

14/ نشأة الفقه الإسلامي وتطوره:

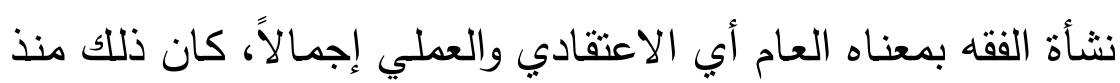

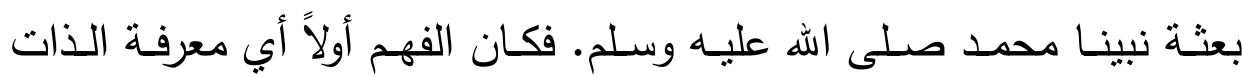
الإلهية، الذي هو أساس كل شيء وهو ما يسمى بالفقه الأكبر - العقيدة- ثم

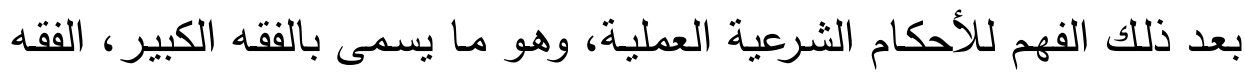
العملي. وكل ذللك مرده كتاب الله وسنة رسوله صلى الله عليه وسلم. 
يقول محمد علي السايس وقد اتجه الإسـلام أول مـرة إلى إصـلاح

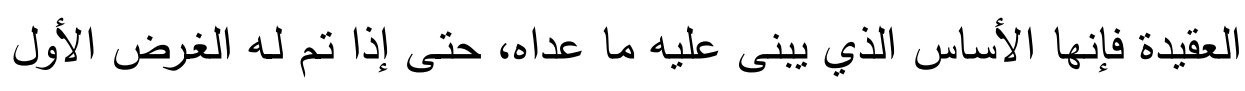
أخذ فيما يليه من وضع نظم الحياة.

ومن أجل هذا ترى القرآن كان ينزل عليه بمكة - قبل الهجرة- معنياً

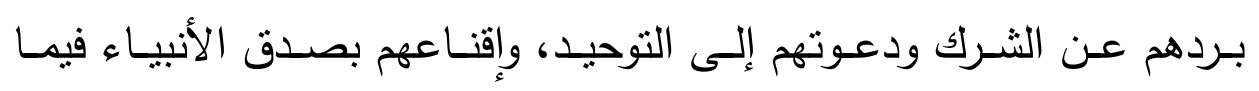
يبلغونهم ويسوق لهم العبرة بالقصص عن الكن الأمم السابقة.

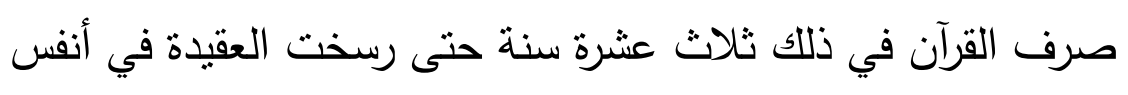

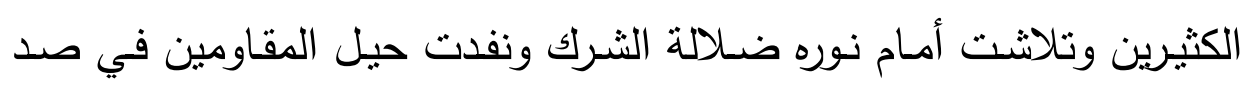

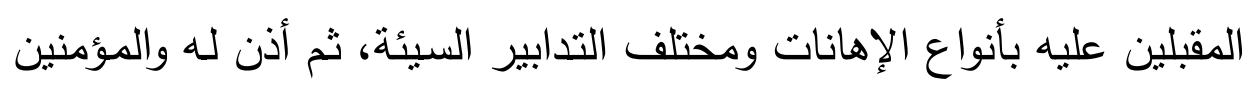

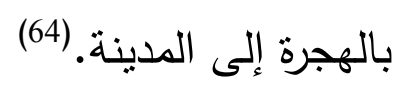
ومنذ ذلك الحين اتجه التثريع الإنسلامي نحو الغرض الثاني فشرع الثان

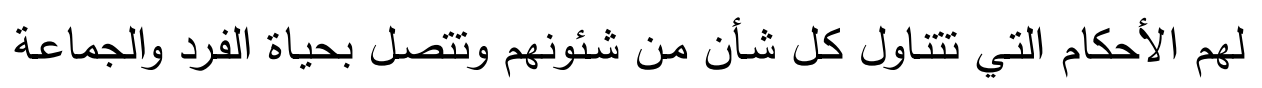

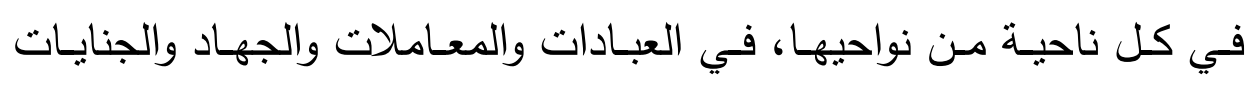

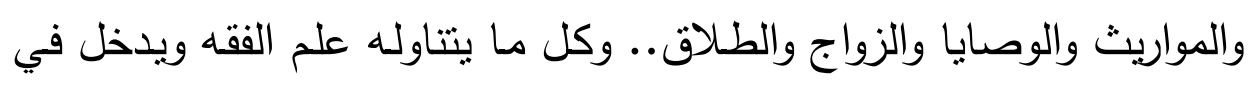
واحد من هذه الأنواع. ويقول د. وهبة الزحيلي: "وقد بدأت نثأة الفقه تدريجياً في حياة النبي صلى النى

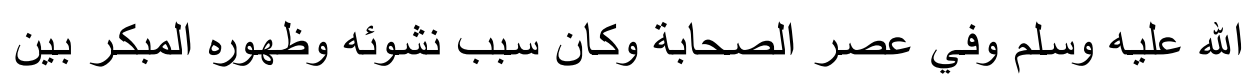

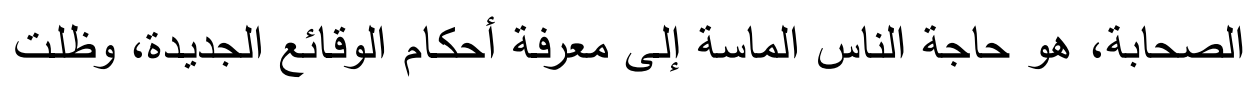

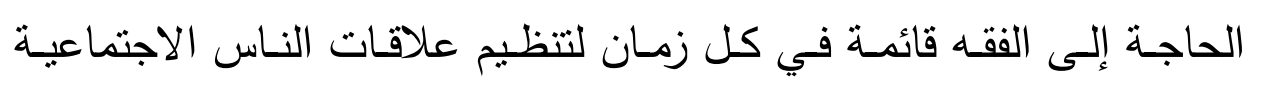

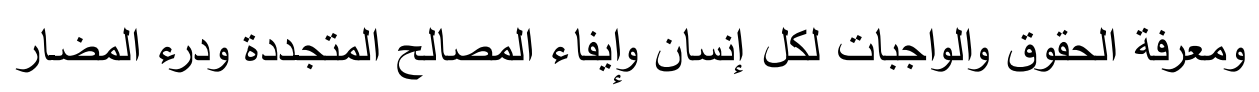

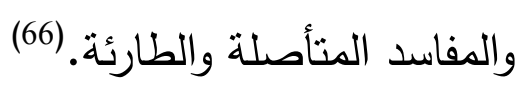


يقول أحمد أمين "جاء رسول الله صلى الله عليه وسلم وأقام بمكة ثلاث عشرة

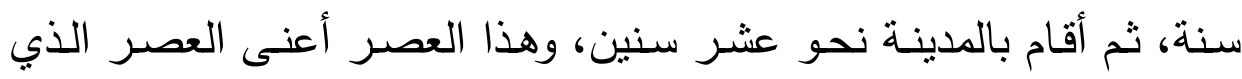

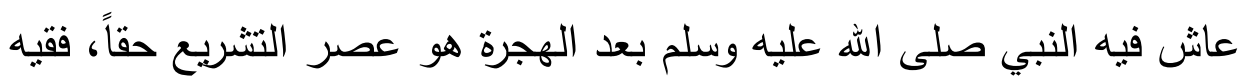

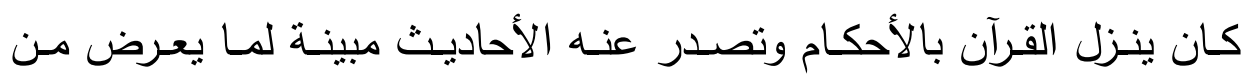

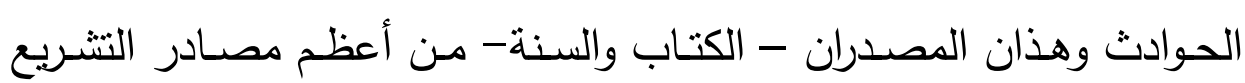
الإسلامي. (67) 15/ تطور الفقه الإسلامي: الإهي:

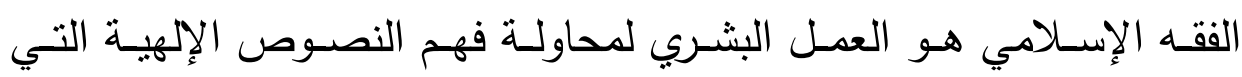

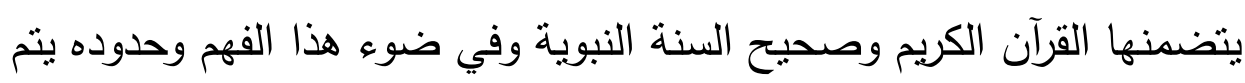
تطبيق نلك النصوص في الواقع العملي. لذا من خلال الاستقراء والتتبع لتأريخ الفقه الإسلامي نجده مر بعدة أطوار : الطور الأول: عصر النبوة. • الطور الثاني: عهد الصحابة عليهم رضوان الله. • الطور الثالث: عهز التابعين. الطور الرابع: عهد صغار التابعين وكبار تابع التابعين.

$$
\begin{aligned}
& \text { الطور الخامس: عهز الاجتهاد. } \\
& \text { الطور الأول- عهر النبوة: }
\end{aligned}
$$

كانت سلطة التشريع والقضاء والفتيا في هذا الطور بيد الرسول صلى الله عليه وسلم وحده فهو المرجع في كل ذلك. وفي عهده تكامل بناء الثريعة في استيفاء نصوصها كما تقدم وقد كان لفظ "الفقه" يطلق في عصر النبوة على على النى كل ما يفهم من نصوص الكتاب والسنة، سواء أكان من أمور العقيدة، أو الو الكئ

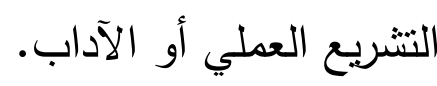


وكان الإسـلام في مكـة متجهاً إلى إصـلاح العقيدة، ومكافحـة الوثثية، أمـا اتجاهل إلى التتريع العملي فإنما كان في المدينة بعد الهجرة.

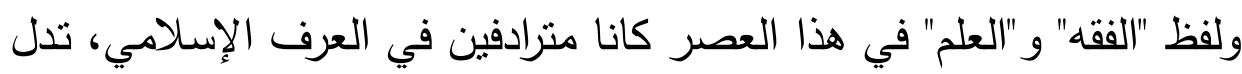

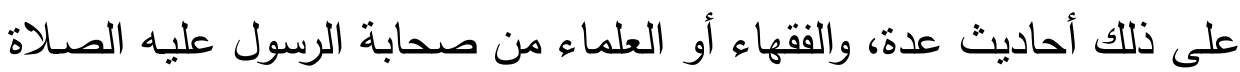
والسلام كانوا بسمون: القراء. (69) وقد كان الفقه في هذا العصر واقعياً لا نظرياً فإنما كان الناس يبحثّن عن ينون حكم الحوادث وبسألون عنها بعد وقوعها أو ينقاضـون فيها فتعالج بـالحكم

الذي تقتضيه الثريعة ولم تكن الحوادث تفترض افتراضاً. (70)

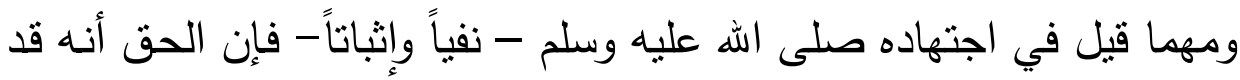

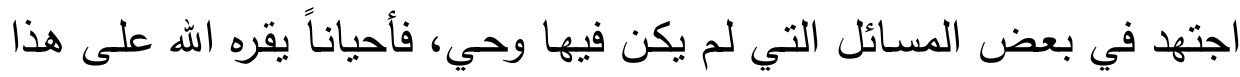

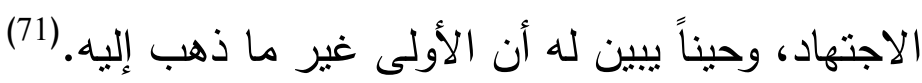
الطور الثاني: عهر الصحابة عليهم رضوان الله: انقضى عصر النبي صلى الله عليه وسلم، الذي كمل فيه التشريع الإسلامي،

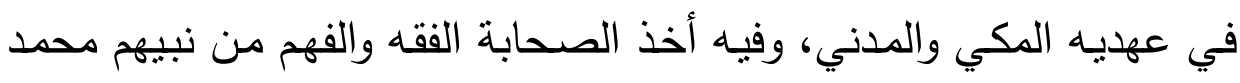
صلى الله عليه وسلم. ثم بعد وفاته صلى الله عليه وسلم انتقل الأمر إليهم.

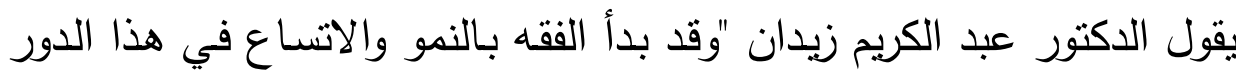
الذي نحن بصدده ذلك أن الفقهاء بعد وفاة النبي صلى الله عليه وسلم واجهوا وقائع وأحداثاً ما كان لهم بها عهد في أيام النبي صلى الله عليه وسلم فكان اندان

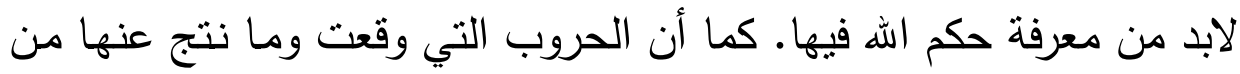
قضايا وعلاقات بين المسلمين وبين غيرهم أثناء الحرب وبعدها أدت إلى كثرة الهـ

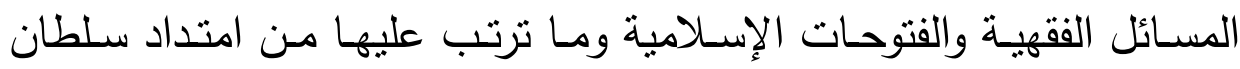
الإسلام على بلاد كثيرة واتصال المسلمين بأهل تلك البلاد ولكل بلد أعرافه 
وعاداته وتقاليده ونظمه كل ذلك أدى إلى ظهور مسائل وقضايا جديدة تستلزم

معرفة حكم الثرع فيها". (72)

ويقول د. مصطفى الزرقا "وقد انتقلت في هذا الدور حال علماء الصحابة من طور إلى طور • فهم في حياة الرسول صلى الله عليه وسلم فإن شأنهم تلقياً

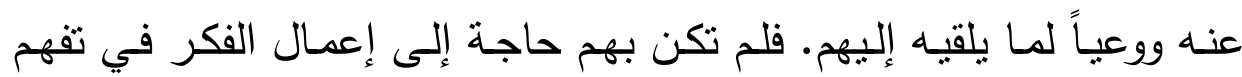
الأحكام المحتاجـة إلى تبصـر ونظر ذلك الإعمال المسمى بالاجتهاد لأن

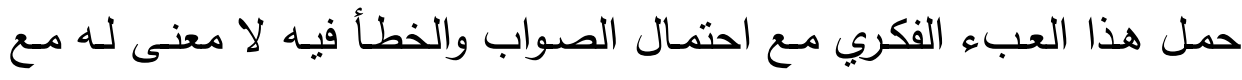

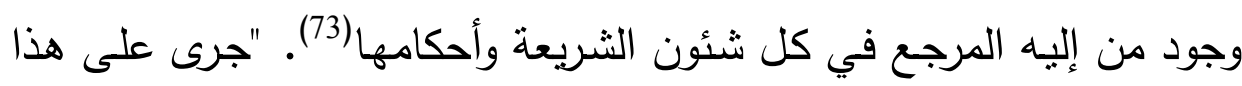

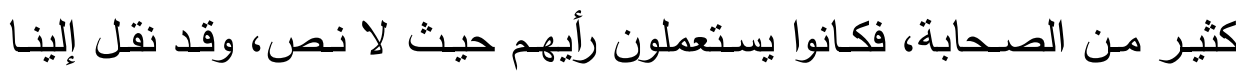

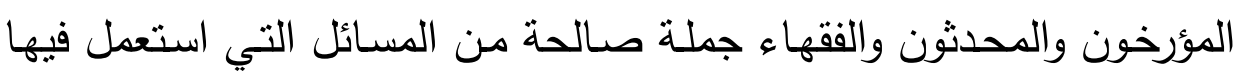
الصحابة رأيهم فلم يكد يتوفى النبي صلى الله عليه وسلم حتى رأوا أنفسهر أمام أكبر مشكلة قانونية وهي من يتولى الأمر بعده صلى الله عليه وسلم.(74)

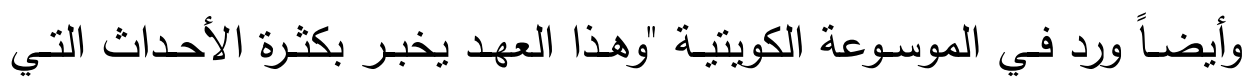
جاءت بعد عهد النبوة لكثرة الفتوحات واختلاط المسلمين بغيرهم من الأمم وهم

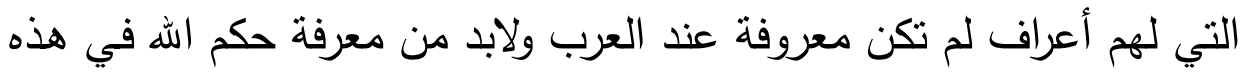

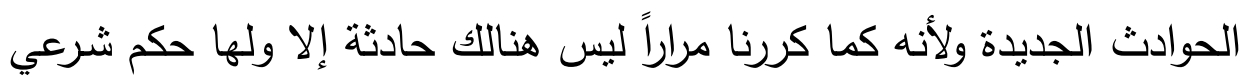

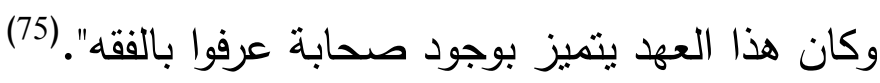
17/ الطور الثالث- عهر التابعين: شريعة سيدنا محمد صلى الله عليه وسلم من أكمل الثرائع وأتمها بل أفضلها على الإطلاق، شريعة جاءت ملائمة ومواكبة لكل عصر من العصور ولكل الكل

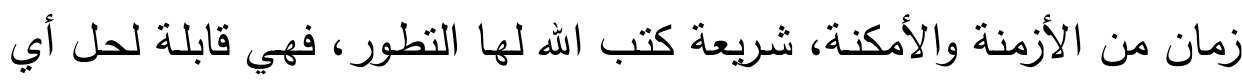


مشكلة تطرأ في حياة الأمة الإسلامية. لذا جاء هذا الدور من التطور في الفقه الإنسلامي بعد عهد النبي صلى الله عليه وسلم وعهد الصحابة الكرام. يبدأ هذا الدور من نهاية عصر الخلفاء الراثندين أي سنة 41هــ إلى أوائل القرن الثاني للهجرة أي قبيل سقوط الدولة الأموية. وقد سار الفقه في هذا الدور على نهج الصحابة في الفقه، لأن التابعين تلقوا

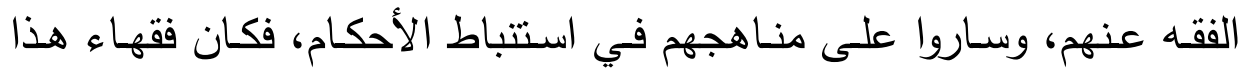
العصر يرجعون إلى الكتاب والسنة ثم إلى الاجتهاد بالرأي بأنواعه ناظرين إلى علل الأحكام ومراعاة المصلحة ودفع المفسدة. (76)

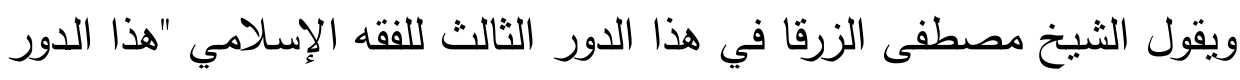

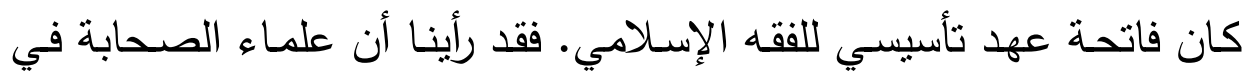

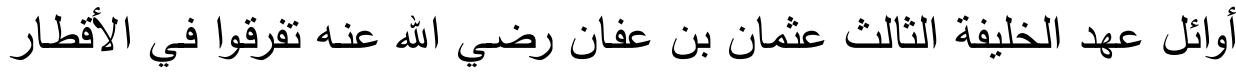

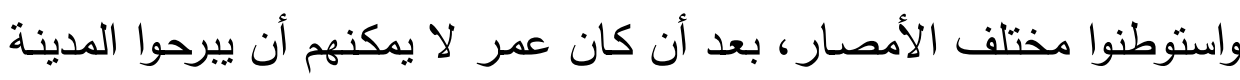

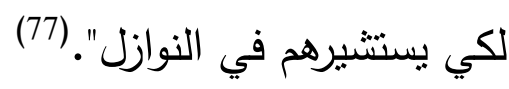
وقد حمل هؤلاء الصحابة إلى مواطنهم الجديدة في الحجاز واليمن والعراق

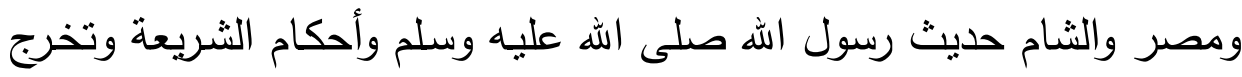
على أيديهم طبقة التابعين في مختلف البلدان. (78) وجاء في الموسوعة الفقهية وهذا الطور امتداد لعهد صغار الصحابة، وقد

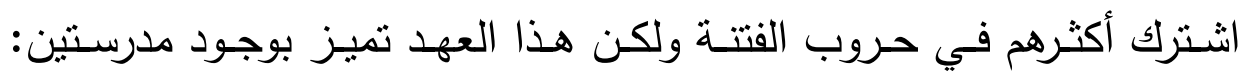

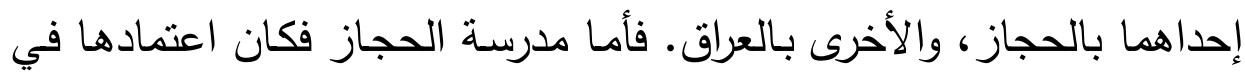
الاجتهاد على نصوص من كتاب وسنة، ولا تلجأ إلى الأخذ بالرأي إلا نادراً،

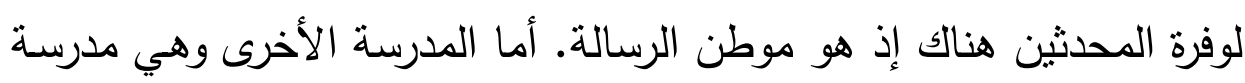


العراق. فكانت تلجأ إلى الرأي كثيراً والرأي عندهم برجع إما إلى القياس الأصولي. وإما رد الكسائل المستحدثة إلى قواعد الثرائل الثريعة العامة". (79) 18/ الطور الرابع- عهذ صغار التابعين وكبار تابع التابعين:

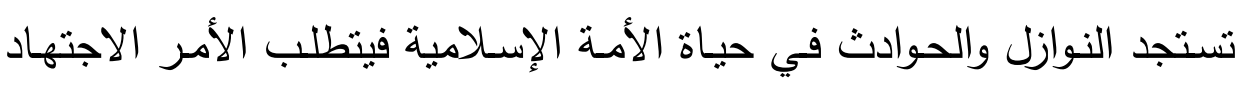
والفهم في شرع اله لإيجاد الفتوى من أجل معرفة حكم الله في هذه النوازل.

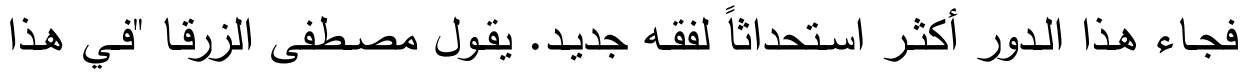

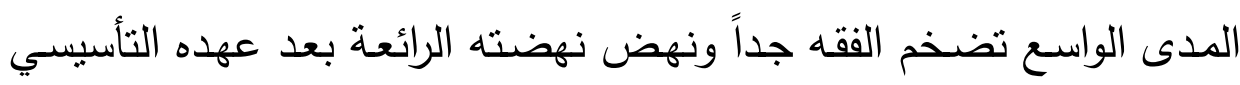

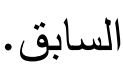
ونثأت في هذا الدور الواسع مذاهب واجتهادات فقهية جمة منها المذاهب

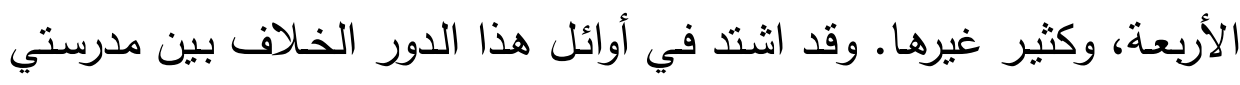

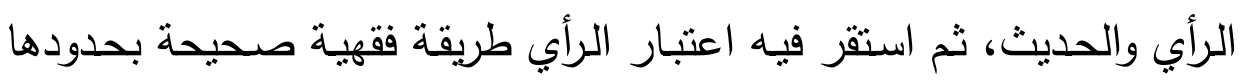

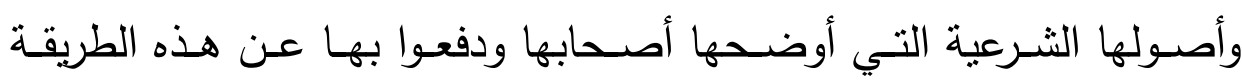
الثبهات بما يبعدها عن معنى القول بالتشهي والهوى الدجرد عن الدليل الثرعي". (80) ويقول عبد الكريم زيدان "يدأ هذا الدور من أوائل القرن الثاني الهجري ويمتد

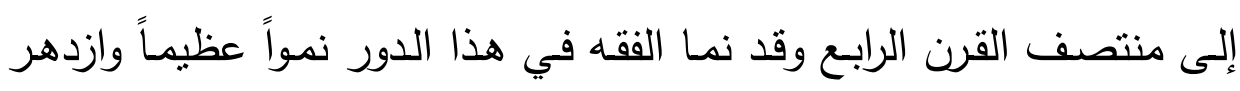

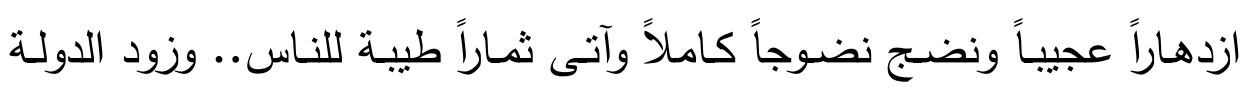

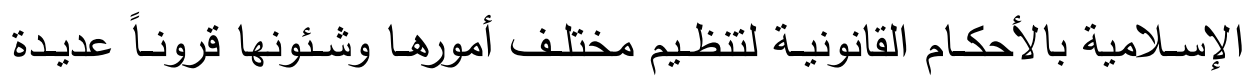
فسعد الناس بنلاك الأحكام ما شاء الله لهم أن بسعدوا". (81) وفي أول القرن الثاني إلى منتصف القرن الرابع الهجري وهو الدور الذهبي

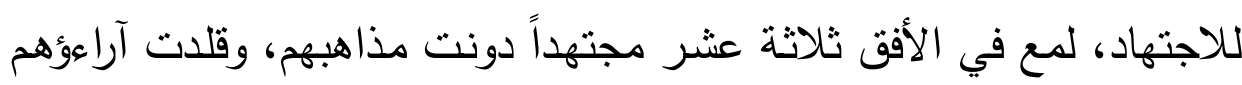
وهم سفيان بن عيينة بمكة ومالك بن أنس بالدينة وأبو حنيفة وسفيان الثثري الثري 
بالكوفة والأوزاعي بالثام والثشافعي والليث بن سعد بمصر وأحمد بن حنبل وداؤود الظاهر وابن جرير الطبري ببغداد.(82) وفي أواخر هذا الطور بدأت تظهر المذاهب الفقهية المتميزة كمـا أن هذا

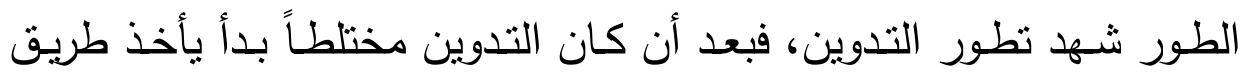
التنظيم. (83)

19/ الطور الخامس- عهر الاجتهاد:

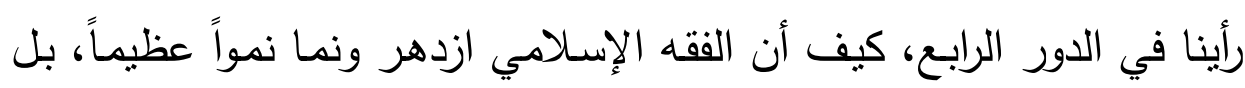

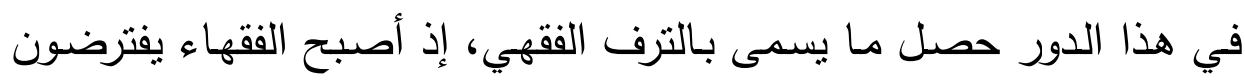
فيه قضايا فقهية قد تقع في المسنقبل ثم يذكرون الفتوى لها. كالذي ألجأه حيوان مفترس إلى رأس شجرة كيف يصلي، أو من أخذت منه ملابسه فصار لونار عرياناً كيف كذلك يؤدي صلاته (84). ثم جاء هذا الدور الذي يعتبر ، أن الفقه فيه شهد تراجعاً عما كان عليه في بدايته وقريباً من نهايته. يقول عبد الكريم زيدان "يبدأ هذا الدور من نهاية الدور الرابع إلى سقوط بغداد

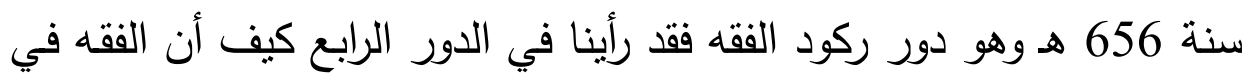

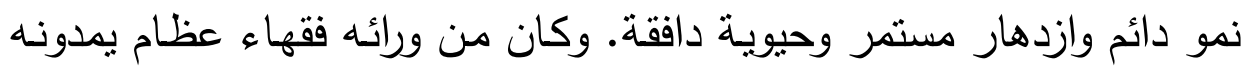

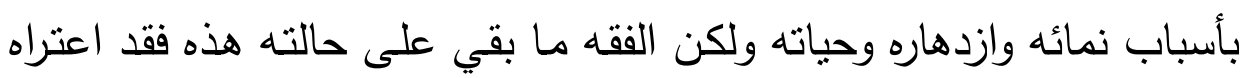

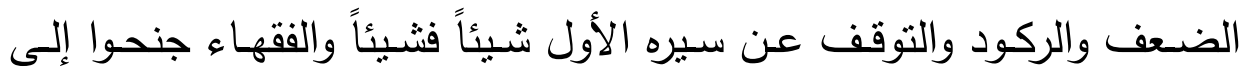

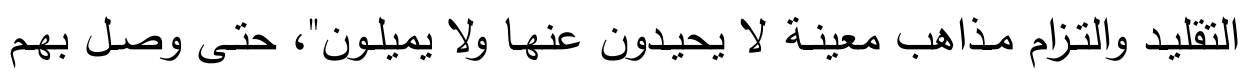
الحال إلى الإفتاء بسد باب الاجتهاد. (85)

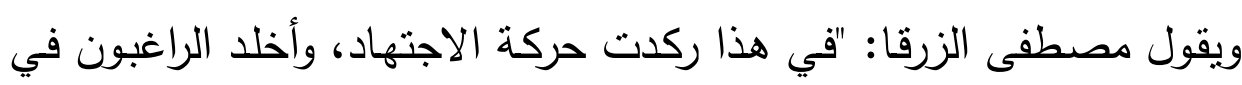
الفقه إلى مذاهب أولئلك المجتهدين السـابقين وخاصـة منهم الأئعـة الأربعـة. 
وتمركز كل مذهب من تلك المذاهب الأربعة في قطر أو أقطار • وتخرج في

كل مذهب فقهاء عظام تتاولوا المذهب بالتدوين والتنقيح والترتيب". مع هذا الركود الذي حصل للفقه الإسـامي في القرن الخامس والسادس، ثم إلى يومنا هذا لكن مع ذلك هنالك الكثير من العلماء اجتهدوا وجاءوا بفقه وفهج لكثير من القضايا التي استجدت في حياة الأمـة. وهكذا سيظل الأمر طالما كتاب الله موجود وسنة رسوله صلى الله عليه وسلم هما. المصدران اللذان لا يبليان من كثرة الأخذ والرد. "يتـاول الفقـه الإســامي جميـع المسـائل التـي تواجـه الإنسـان في حياتـهـ الثخصية والدينية والاجتماعية والاقتصادية ويضع القواعد الني تنظم حياته،

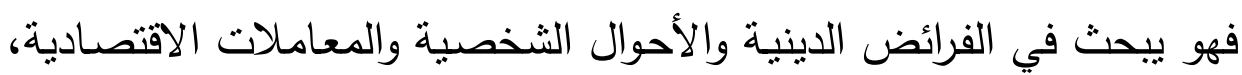
وفي الجرائم وعقوبتها، وقد مر الفقه بتطورات هامة، وأنتج حركة رائعة من حيث ضخامة الإنتاج وعدد العلماء والفقهاء وابتكار الأساليب في الاجتهاد والتعبير اللغوي والمصطلحات، ووضع القواعد التي تساير تغير الظروف،

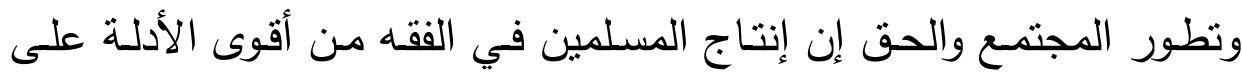
خصب الثقافة الإسلامية. (86)

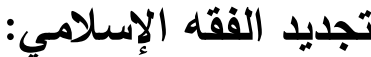

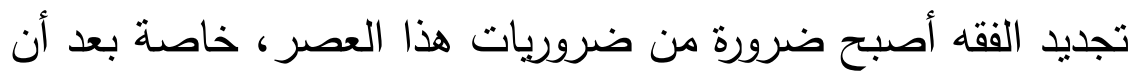
بعدت الأمة الإسلامية عن الاهتمام بالعلم الثرعي ومدارسته وانكباب أبنائها

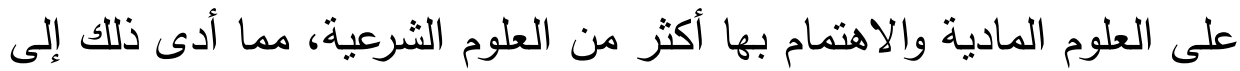
فنشو الجهل وتخلف الأمة في شتى ميادين المعرفة. لذا إذا لم تغير الأمة الإسلامية من حالها هذه ويلجأ علماؤها إلى فهم كتاب الله وسنة رسوله صلى الله عليه وسلم وتطبيقه في واقع الحياة ثم القيام 
بالاجتهاد فيما يستجد ويقع من نوازل لتعطلت حياة الأمة، ثم ستصبح من

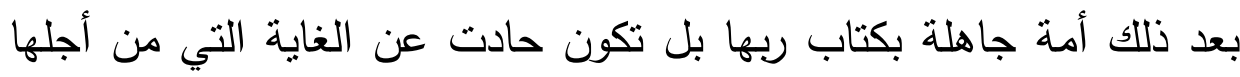

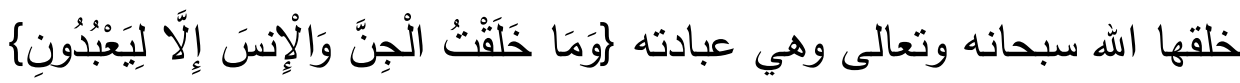

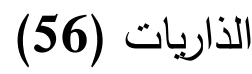

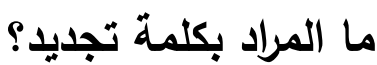
التجديد في اللغة: "تجدد الثيء يعني صار جديداً وجدده أي صيره جديداً،

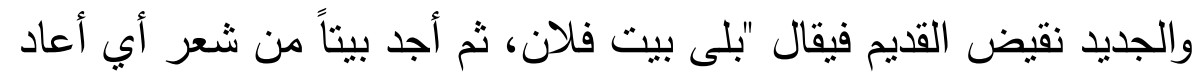
بناءه ويقال جدد الوضوء أي أعاده وجدد العهد أي كرره وأكده(87).

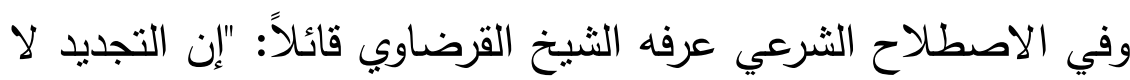
يعني أبداً التخلص من القديم أو محاولة هدمه بل الاحتفاظ به، وترميم ما

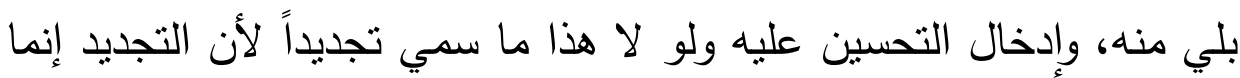
يكون للثيء قديم"(88). وعرف أيضاً: "تجديد الدين عند العلماء معناه إحياء ما اندثر منه وتوجيه الناس إلى العمل بما نرك من شعائره"(89. وجاء في الحديث عن الرسول صلى الله عليه وسلم قوله: " إن الله يبعث لهذه الأمة على رأس كل مائة سنة من يجدد لها دينها" (رواه أبو داود)

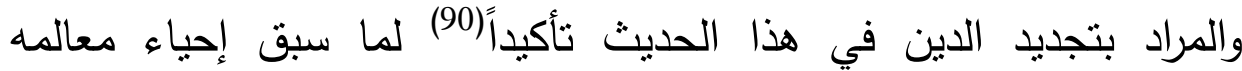
العلمية، والعملية التي أبانتها نصوص الكتاب والسنة وفهم السلف(91). 
ومما سبق يتبين أن التجديد في أصل معناه اللغوي وفي استعماله النبوي يدل على الإحياء والبعث والإعادة. ولذا لا يخرج التجديد عن ثلاث معان يستلزم كل واحد منها الآخر. الأول: إن الثيء قد كان في أول الأمر موجوداً أو قائماً. الثاني: إن هذا الثيء أنت عليه الأيام وصار قديماً. الثالث: إن ذلك الثيء قد أعيد إلى منل الحالة التي كان عليها لإنبل قبل أن يبلى.

\section{مفهوم التجديد المنشود:}

التجديد الذي نريده بل نتمناه لديننا الإسلامي، هو إعادته في نفوس

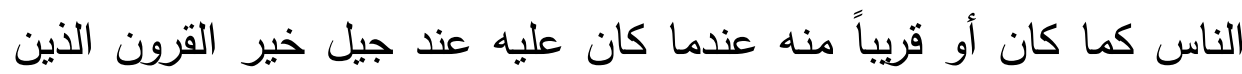

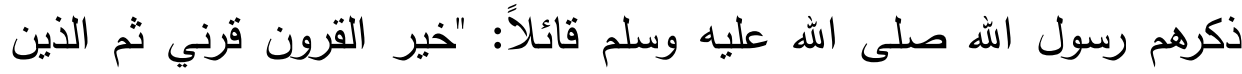
يلونهم ثم الذين يلونهم ... والخير في أمتي إلى يوم الدين".

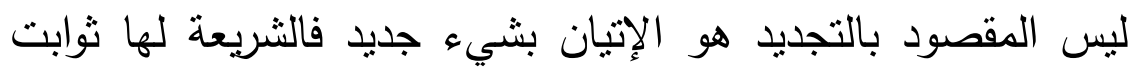
كما لها متغيرات وهذا الذي جعلها صالحة لكل زمان ومكان وجعلها خير

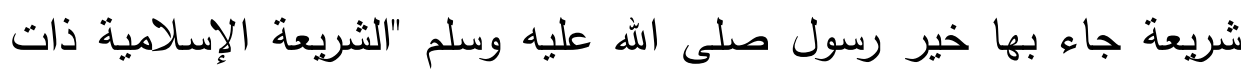
المصدر الإلهي اثتثلت على أحكام ثابتة لا تتغير وأحكام قابلة للتغير والنطور، تحقيقاً لمبدأ مرونة الثريعة وإعمالاً لعقول علماء الأمة وانسجاماً

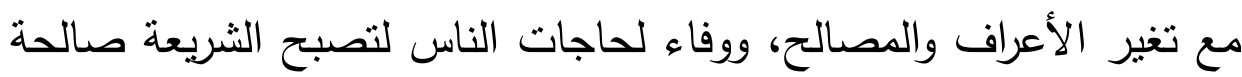
للنطبيق في كل زمان ومكان (92).

"ولعل أول ما نحتاجه في هذا الصدد هو تقديم اجتهادات جديدة في

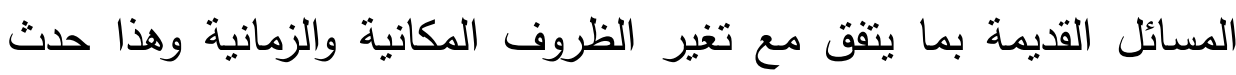
كثيراً مع الإمام الثافعي، فالاجتهاد حركة دائمة مستمرة والآراء الاجتهادية أياً 
كانت منزلة أصحابها من الفقهاء لا يجوز إسباغ صفة الثبات عليها فالثبات

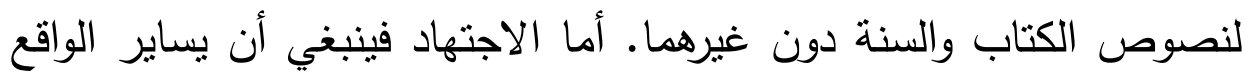

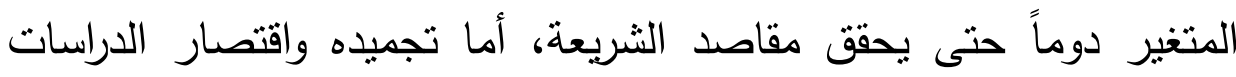

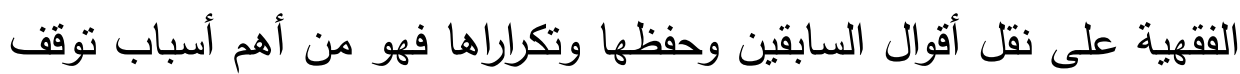

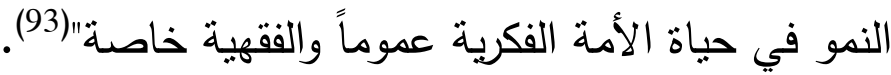
"وفي ضوء هذا المفهوم للتجديد ننظر إلى فقهنا الإسلامي في هذا العصر الذي أصبح طابعه التغير والتغير السريع".

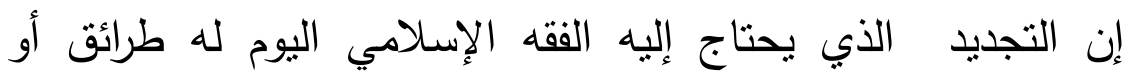

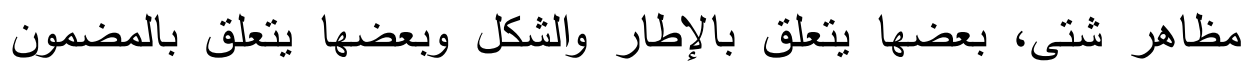
والمحتوى وينبغي أن نلقي الضوء عليه حتى تتضح معالمه.

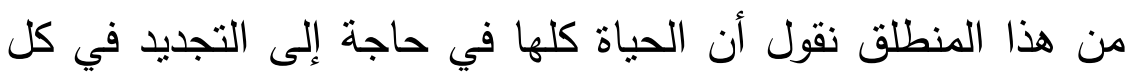

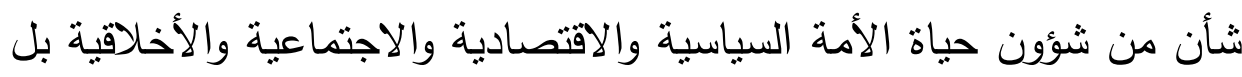
منهج حياتها كلها. "ويمكن القول أن التوجه صوب دراسة حركات التجديد والإصلاح ومناهجها وإعادة تقويمها ونقدها وبيان الإصابات التي لحقتها يكون ذللك بياناً وهدى وموعظة ووقاية وإغراء بالتجديد والاجتهاد أمر يبشر بالخبر وبمستقبل واعد لحركة الوعي الإسلامي المعاصر في حراكها العلمي والمعرفي (94).

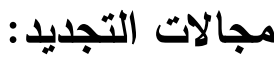

بالنسبة لأحكام العبادات كالصلاة، والصوم، والحج، والزكاة فهذه ليست بحاجة إلى تجديد، لأنها كلها ثبتت بنصوص من القرآن الكريم أو سنة وانة واهن

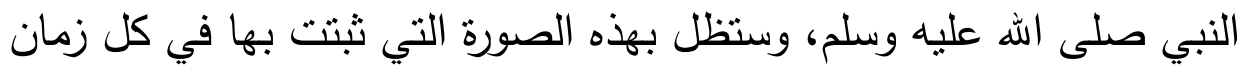
وفي كل عصر إلى أن يرث الله الأرض وما عليها. 
"فلا يصح نغيير أعداد وأحوال الفرائض، من صلاة وصيام وحج وزكاة لأنها شرعت بقصد تعبدي وتظل مطلوبة على النحو الذي شرعه الثارع لكن يصح تغيير بعض كيفيات العبادة كأداة الصلاة في وسائل النقل الحديثة من طائرة كأداء أو سيارة أو في القمر الصناعي أو الدحطة الفضائية على النحو المككن من غير قيام ولا اتجاه نحو القبلة"(95). ويمكن النظر في ثبوت الهلال بالصورة الحديثة أي معرفة أهل الإرصاد الجوي وبعض الأمور التي تتعلق بما يفطر الصائم أو لا يفطره. وكنلك أداء مناسك الحج يمكن التيسير فيها على الحجاج بسبب مشقة الزحام التهام

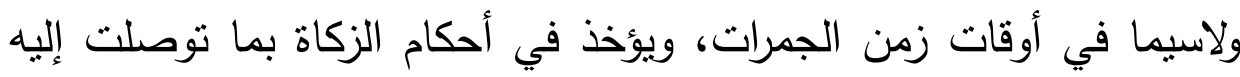
ندوات هيئة الزكاة المعاصرة في تطوير ومساعدة الفقراء والمساكين من فئن طريق تأسيس مصحات أو مراكز طبية مملوكة لجماعة من الفقراء والمساكين. وأما فيما يتعلق بأحكام الأسرة من تجديد أو (الأحوال الثخصية) فإن

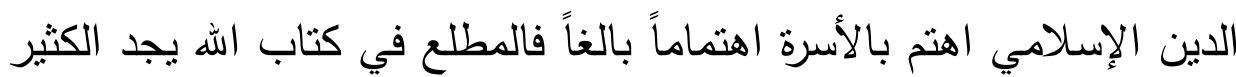

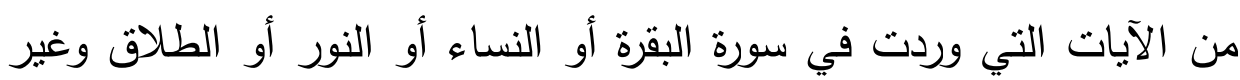
ذللك من آيات وأحاديث نبوية حفلت بالحديث عن أحكام الأسرة ومكانة الأسرة

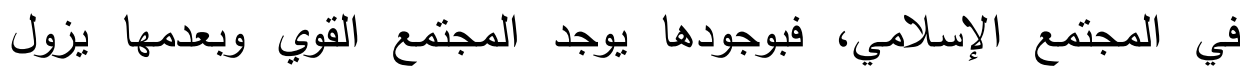

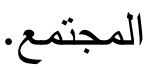

لذا "فلا يجوز المساس فيها بنظام التعاقد الثرعي، بإيجاب وقبول في مجلس واحد وبحضور شاهدين عدلين ولا بالطلاق فهو حق للرجل إلا إذا فاليا

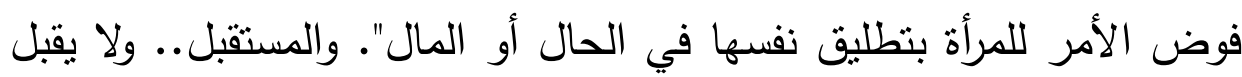


القول بعدم وقوع الطلاق حال الحيض ولا حاجة للإثهاد عليه أو على

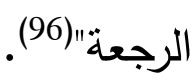

فالتجديد لأحكام الأسرة ليس الإتيان بجديد فيما يتعلق بأحكامها وإنما

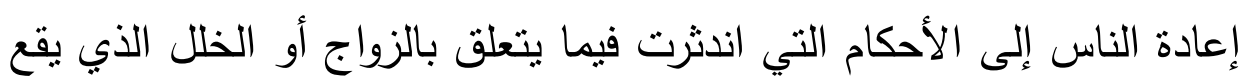

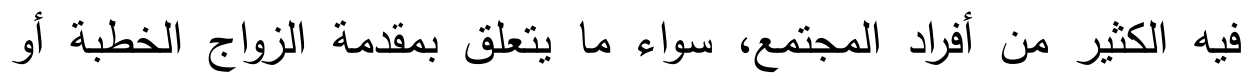
اختيار الدرأة وفق الهدي النبوي الثريف وهو الحض على الثراء الدرأة الصالحة،

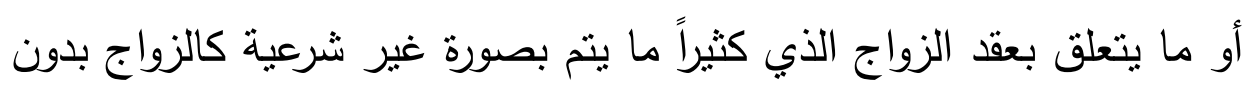

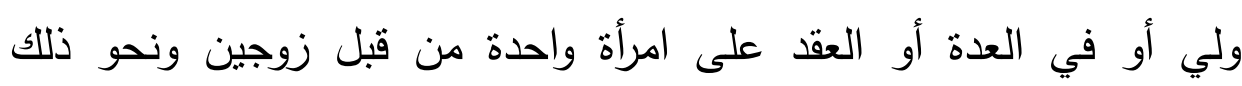
الكثير الكير

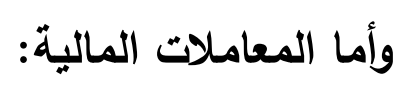

قد اهتمت الثريعة الإسلامية بالمال اهتماماً بالغاً، وحضت المرء

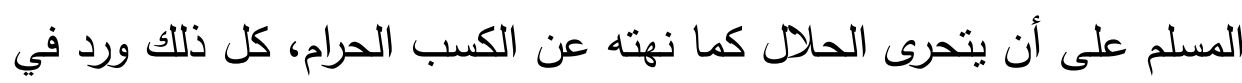
كتاب اله وفي سنة رسول الله صلى الله عليه وسلم نصوصاً واضحة وصريحة فيما أحل اله أو نهى عنه والسنة كذلك تحل ما أحل الكال الكتاب وتحرم

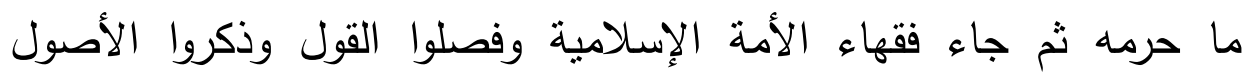

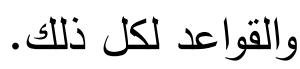

يقول الدكتور وهبة الزحيلي "وأما أصول المعاملات فلا يجوز تجاوزها كالتراضي في العقود والوفاء بالعقود، والتزام كل طرف بالمال بما وجب عليه وضمان الضرر المترتب على الآخرين بفعل الثخص والتقبد بالثروط

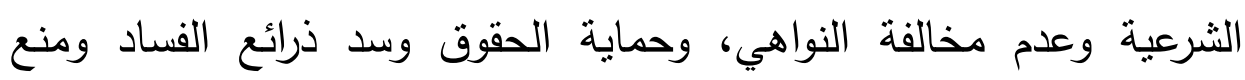
التعسف في استعمال الدق في علاقات الجوار ونحوها، وسريان الإقرار على التى 
نفس المقر ، ولا مانع من التجديد في أوضاع المعاملات عرفاً إذا لم تخالف مقتضى العقد، ولا أصول الثرع(197). من التجديد في المعاملات المالية التي نحن معشر المسلمين في حاجة إليه هو التعامل مع الدول غير الإسلامية أوروبية وغيرها فهذه الدول

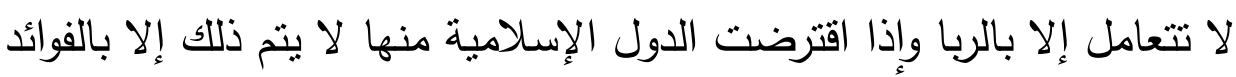
الربوية ونحن نعلم يقيناً أن الربا محرم ولم ينسخ وغير ذلك من المعاملات

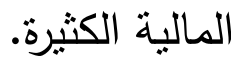

وكذلك هناللك معاملات استحدثت في حياة الأمة الإسلامية، منها

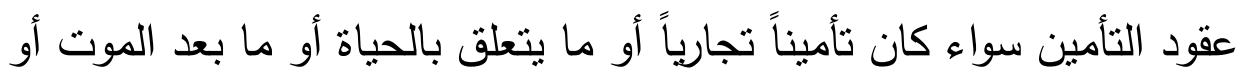

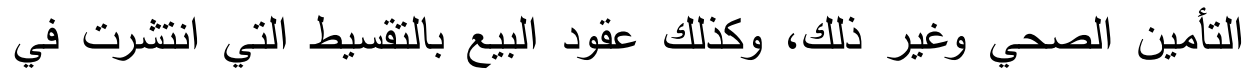
المجتمع بصورة أوسع وغير ذلك الكثير من العقود المستحدثة في حاجة إلى لى لئ

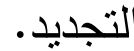

والضابط لكل هذا التجديد في المعاملات المالية يتم فيه الرجوع إلى

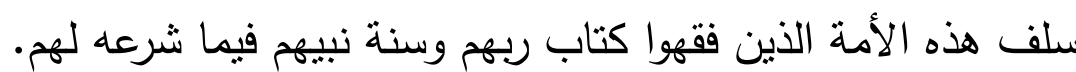

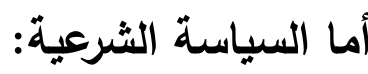
"موضوع النظام السياسي للدولة الإسلامية أحد الموضوعات، بالغة الأهمية التي تقتضي من أهل التخصص العناية ببذل الوسع كله لتقديم فقه

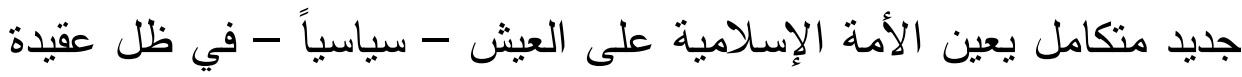

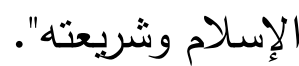

وقد نال هذا الجانب من جوانب الفقه الإسلامي من عناية الفقهاء

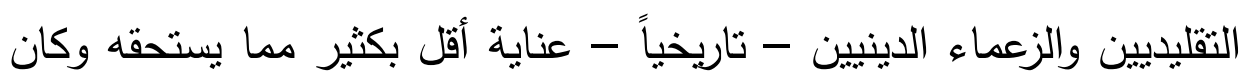


الحكم الفعلي يمضي في جانب والفقه السياسي يقف في جانب آخر ، أحياناً لا يكترث بما يفعله الحكام وذوو الجاه والنفوذ والسلطان (98). يقول الثيخ القرضاوي وهو يتحدث عن "فقه الدولة" وهو فقه قصر فيه

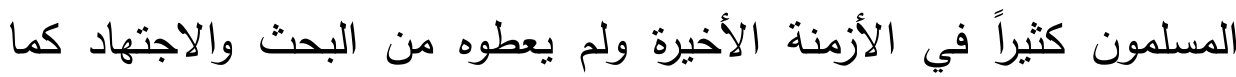

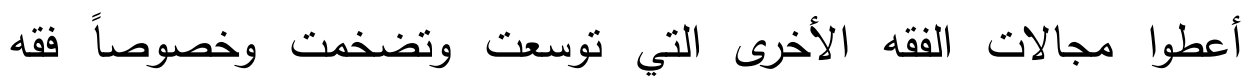
العبادات(99).

وتقول الأستاذة حليمة بوكروشة "فقد أحاطت بالفقه الإسلامي في بعض أدواره التاريخية عوامل سياسية واجتماعية وعلمية تضخم على أنزها

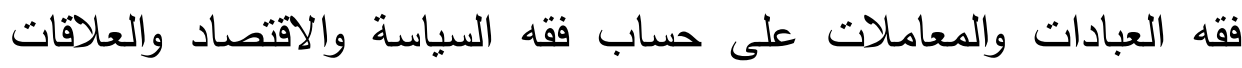
الدولية كما تغيرت بفعل تلك العوامل تركيبة المنظومة الفقهية فأصبح التقليد

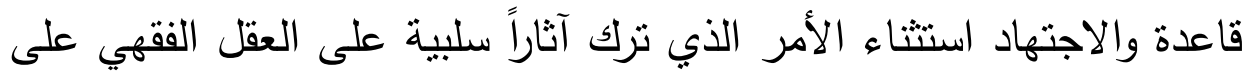
مستوى المنهج والإنتاج"(100). "لقد كان لاستحكام التقليد وظهور دعوى غلق باب الاجتهاد الأثر

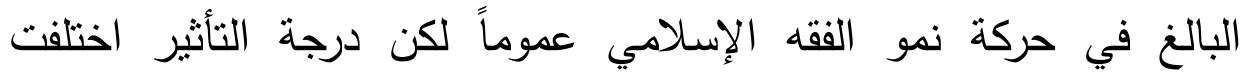
باختلاف الموضوعات الفقية، فقد استمر فقه الفرد - عبادات، معاملات على ما أصابه من جمود ضمن الممارسة اليومية للمسلمين واستمر الوعي به وتدريسه للمتعلمين، في حين إن فقه الدولة "|فتصاد، وسياسة، وإدارة... الخ" ضعف وعي المسلمين به وأصبحت تصورات كثير من العلماء في عصر الإمام الثوكاني يحكمها إما تبرير الواقع والخضوع له، أو رفضه لهن واعتزاله"(101).

أما الإمام الثوكاني فإن ممارسته للعمل السياسي، وتوليه لمنصب القضاء العام، منحاه فرصة المشاركة في تخطيط وتتفيذ برامج الدولة 
السياسية والاقتصادية والإدارية والاجتماعية، الأمر الذي جعل فكره الفقهي على قضايا المجتمع العامة ومن ثم ينعكس على إنتاجه الفقهي الذي لم الماديه يتوقف عند حفظ وشرح التراث السياسي والاقتصادي الموروث بل تعداه إلى

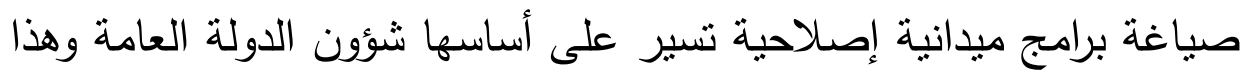

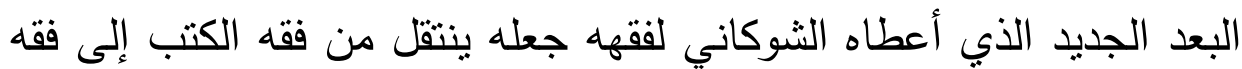

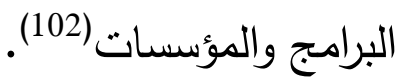

لذا لا مانع من التجديد فيما يتعلق بفقه السياسة الثرعية بل التجديد

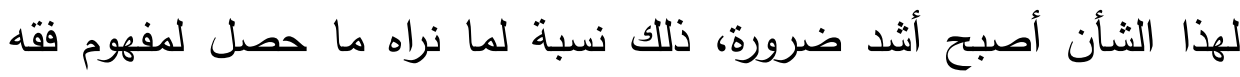
السياسة من جهل عظيم عما كان عليه سلف الأمة الإسلامية وعلى وجه الخصوص العهد الراشدي، أولئك الذين فقهوا تمام الفقه كيف يسوسون المسلمين وذلك من منطلق كتاب الله وعلى منهاج رسول الله صلى الله عليه وسلم، فعانت الأمة الإسلامية أسمى حياتها في ظل الخلافة الإسلامية، لأن في تطبيق شرع اله كل العدالة والحرية والمحافظة على كل الحقوق الاستله والواجبات، لا ظلم ولا جور إذ كان المنهل الذي نهل منه هؤلاء لقيادة الأمة

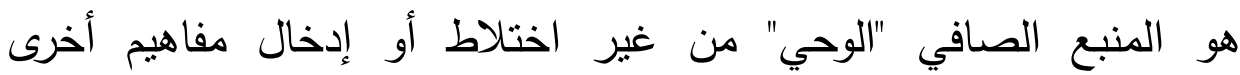
كالديمقراطية والحرية المطلقة التي في دول الغرب وصلت إلى إعطاء الحريات المطلقة من غير تقييد بقيم وأخلاقيات المجتمع فوصل الأمر إلى دئ إلى إعطاء الناس حريتهم حتى فيما يسمى بالثذوذ الجنسي الذي أصبح له قانون

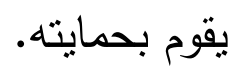

بل ليس هناللك صراع على السلطة أو على الحكم لأنها أمانة وهم يعرفون حكم من يسعى لها أو يتولى أمر الناس لذا لا صراع حزبياً أو طائفياً

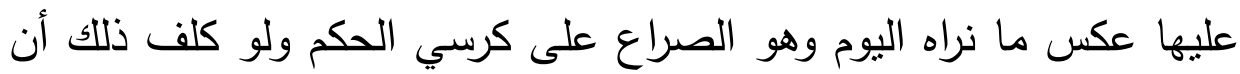


يكون على حساب الدين أي إسقاط شرع اله وعدم التقيد بالدين في أمر

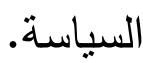

والصراع الآن على أثنده فيما يسمى في هذه الأيام بالربيع العربي، رأينا ذلك في تونس والجزائر وليييا ومصر الآن.

فهؤلاء أي أصحاب الحركات الإسلامية بريدون أن يحكموا أو يسوسوا

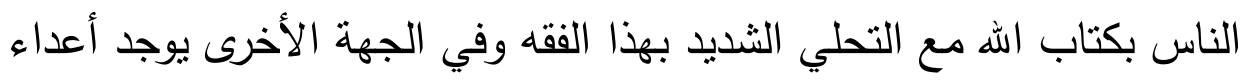

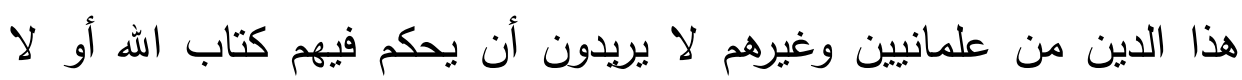
بريدون أن يتخل الدين في السياسية.

\section{فالتجديد المنشود فيما يتطلق بهذا الفقه يتلخص في الآتي:}

أولاً: الحاكمية التي ينبغي أن تكون له الواحد الأحد، فهذه ينبغي أن يته

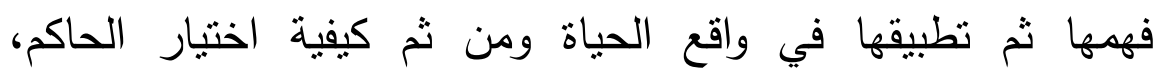
والاختيار هذا يكون وفق الثروط التي ذكرها العلماء. ثانياً: البيعة أي مبياعة الحاكم الذي تم اختياره، والبيعة هي عبارة عن عقد التياء

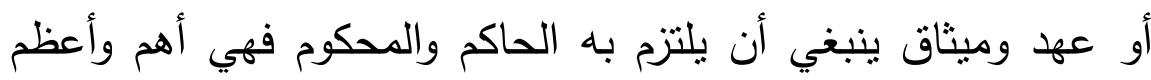

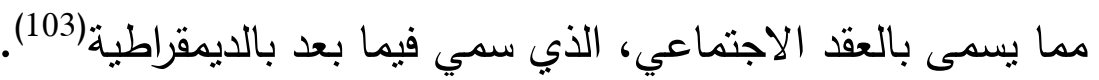

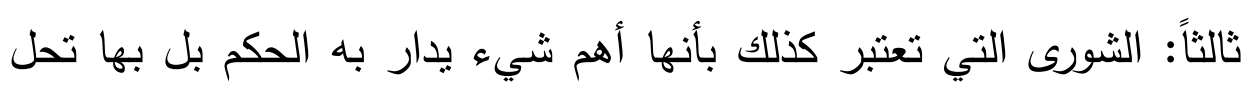

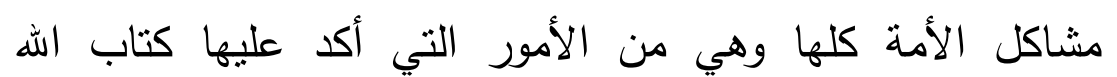

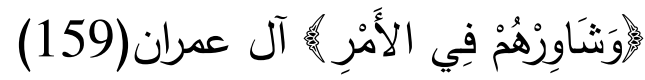
وفعلها رسوله الله صلى الله عليه وسلم في أكثر من موضع (104) الهئ.

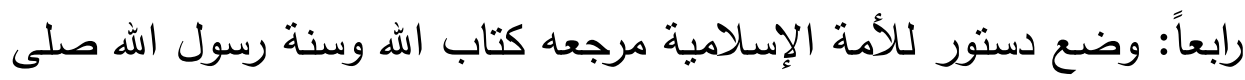
الله عليه وسلم بحيث لا يكون تعبيراً عن أهواء البشر وأخطائهم 
كاختلاط القانون الإسلامي بالقوانين العلمانية ويجب كذلك الالتزام بهذا الدستور من قبل الحاكم والمحكوم.

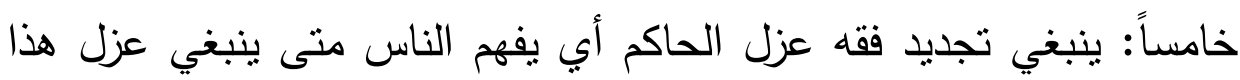

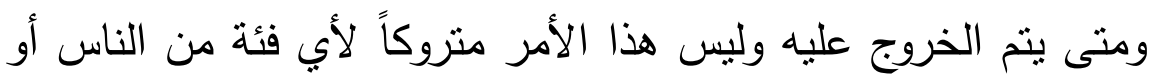

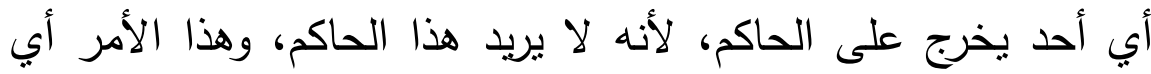

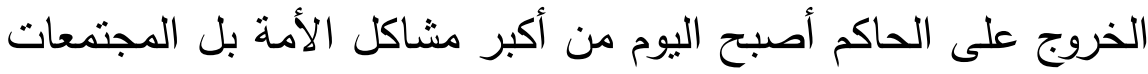

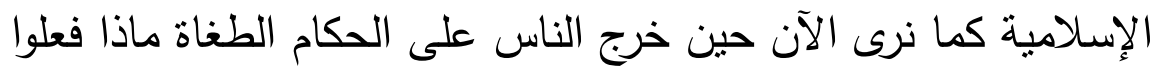
بهم الموت والسجون والدمار نموذج الآن الثعب السوري.

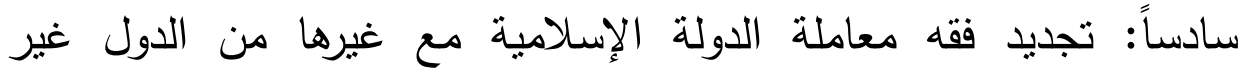

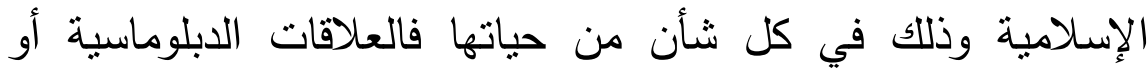
المعاملات المالية كتعامل الدول غير الإسلامية بالفوائد الربوية وغير

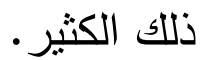
وأخيراً نقول إن الأمة الإسلامية اليوم في أثند وأمس الحاجة إلى أن

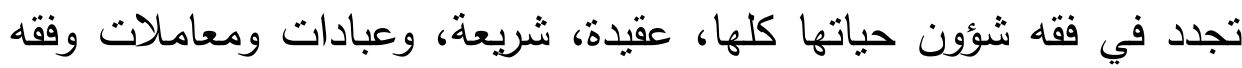
أسرة ونحو ذلك.

يقول القرضاوي "والتجديد للدين ليس فكرياً فحسب كما هو مفهوم الكثيرين عندما يذكرون التجديد ويتحدثون عنه، فلا يكاد يدور بخلدهم إلا لإنيا

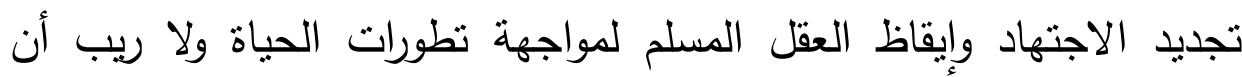
تجديد الفكر، وإحياء الاجتهاد وتصحيح الفهم تأتي في طليعة التجديد المنشود فإن العلم يسبق العمل، والفكرة تسبق الحركة(105). 


\section{النتائج والتوصيات}

النتائجج:

نسبة لتفثي الجهل في حياة الأمة الإسلامية، بحيث أبعدها عن الفهم الصحيح لدينها وجعل أبناءها فرقاً وشيعاً، وأقعدها حضارياً وكانت في يوم من الأيام الأمة العالمة والمتحضرة فإذن لابد من فقه جديد حتى تتهض حضارياً مرة أخرى، إذن هي في أثند الحاجة إلى فقه جديد يناسب واقع حياتها. الققه الإسلامي فقه يمتاز بالموضوعية والثمولية والمرونة وكذللك الوسطية كما أنه فقه قابل للبقاء وليس للاندثار وذلك للوفاء بحاجات الناس ومصالحهم المشروعة. الأحكام الفقهية ليست هي المحصورة في أحكام العبادات صلاة وصوم وزكاة وحج أو المعاملات المالية بل هي أكثر من ذلك كأحكام فقه الأسرة وأحكام السباسة الثرعية والأخلاق بل هنالك أحكام تتعلق بالعلاقات الدولية الأخرى غير المسلمة. الفقه الإسلامي فقه متطور ومتجدد بل قابل لحل أي نازلة تطرأ في حياة الأمة الإسلامية، وذلك بتم بالرجوع إلى تلك المصادر الأساسبة والتبعية. الفقه الإسلامي له مكانة عظيمة ومهمة في حياة الأمة الإسلامية فلا تستطيع أن تعيش الأمة بدون فقه صحيح في واقع حياتها. 
التوصيات:

ينبغي على علماء الأمة الإسلامية، أن يولوا الفقه الإسلامي عناية فائقة تتلخص في الآتي:

1. إنشاء كليات علمية مختصة بالفقه الإسلامي، تهتم بدراسة كتب أئمة

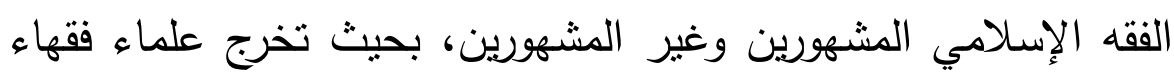
أكفاء.

2. مراجعة وتمحيص ما ذكره الفقهاء منذ العهذ النبوي ومروراً بعهد التابعين

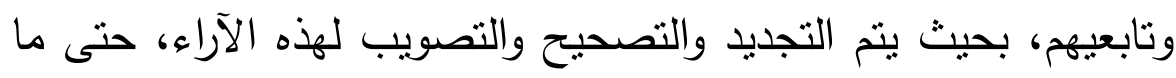
تعلق بفقه العبادات والنوازل وغيره. 3. إنشاء مجامع فقهية في كل البلدان الإسلامية، وتكون هناللك صلة بين

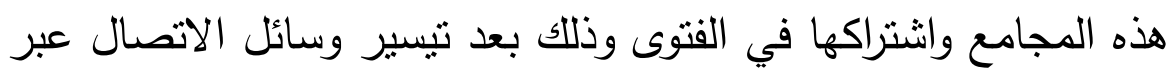
الوسائط الرقمية النت وغيره.

4. ربط الفقه الإسلامي بواقع حياة الأمة بحيث يثمل جميع شئون حياتها من منطلق الفهم الصحيح لكتاب الله وسنة رسول صلى الله عليه وسلم. 5. الاهنمام بأن تكون الفتوى صحيحة من غير فتح الباب لكل أحد يفتي

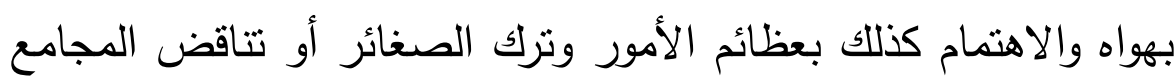
الفقهية في الفتوى، فنرى اليوم هناللك فتاوى تصدر من علماء تنتعلق بجرم صغير ويترك الأمر الكبير . 
المصادر والمراجع: - 20 - (1)

ابن منظور ، لسان العرب، دار المعارف، 3250/5.

ابن فارس، معجم مقاييس اللغة، دار الكتب العلمية، 442/4.

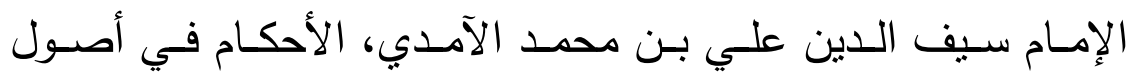

الأحكام، دار الفكر، 5/1.

الراغب الأصـفهاني، المفـردات في غريـب القـرآن، سـيدنا الحسـين

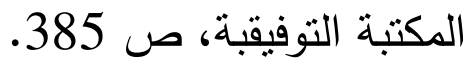

الموسوعة الفقهية، وزارة الأوقاف الإسلامية الكويت، 11/1.

الإمام البخاري، كتابه الصحيح، 22/1. والإمام مسلم، 1827/2.

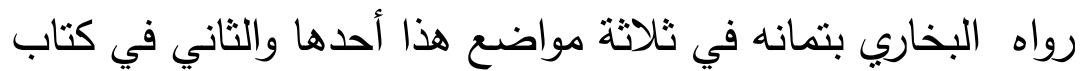

فرض الخمس ورواه "مسلم في كتاب الزكاة" ورواه الترمذي وابن حبان

في صحيحه ورواه الحافظ المنذري.

الموسوعة الفقهية، ص صد ورواه 12.

د. عبد الكريم زيـدان، المـذخل لدراسـة الثـريعة الإسـلامية، سـوريا،

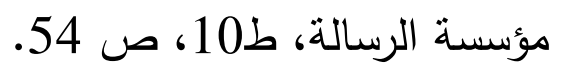

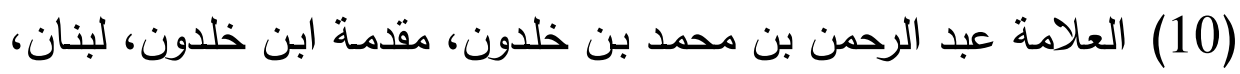

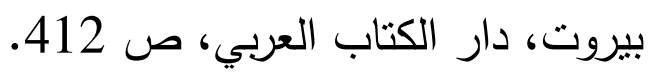

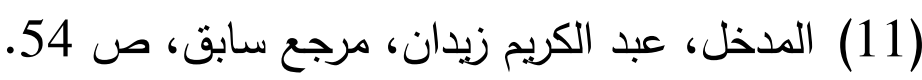

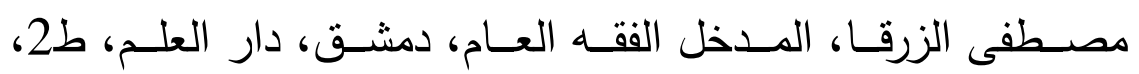

$$
\text { 66/65/1 }
$$

(14) المدخل لدراسة الثريعة الإسلامية، عبد الكريم زيدان، ص له 55. 
(15) أ.د. محمد عثمان سبير ، تكوين الملكة الفقهية، كتاب الأمـة، قطر ،

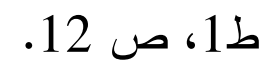

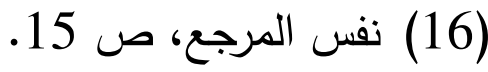

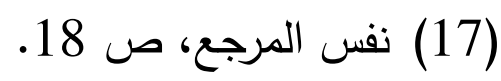

(18) أحمد محمد الفيومي، المصباح المنير، صد صد 310.

(19) محمد بن أبي بكر عبد القادر الرازي، مختار الصحاح، لبنان، دار لهير،

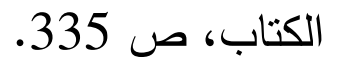

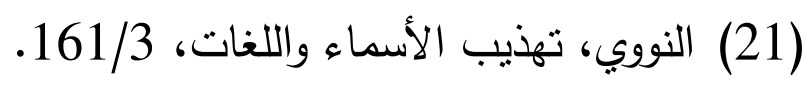

(22) زيدان، مدخل إلى الثريعة، ص 34. والموسوعة الفقهية، 16/1.

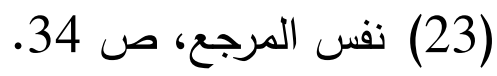

(24) مصطفى أحمد الزرقا، المدخل الفقهي العام، دمثق، دار القلم، ط2،

$$
\text { 153/1 2004م، دم: }
$$

(25) عبد الكريم زيدان، المدخل للشريعة الإسلامية، ص 56.

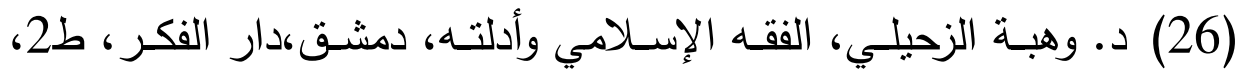

$$
\text { 32/1 2002 }
$$

(27) د. يوسف القرضاوي، الفقه الإسـلامي بين الأصالة والتجديد، القاهرة،

$$
\begin{aligned}
& \text { مكتبة وهبي، ط3، 2009م، ص دمس } 10 . \\
& \text { (28) عبد الكريم زيدان، المدخل، ص } 58 .
\end{aligned}
$$

(29) د. القرضاوي، الفقه الإسلامي، ص 129 13، 12، 14.

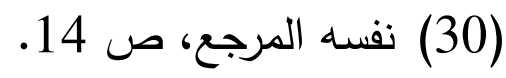

(31) الفقه الإسلامي بين الأصالة والتميز ، مرجع سابق، ص صد 11-12. 
3صطفى الزرقا، المدخل الفقهي العـام، 66/1- 67. ومدخل إلى

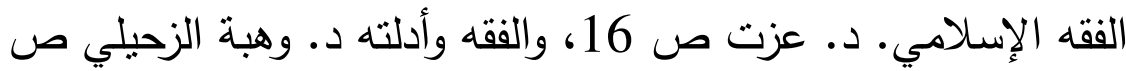

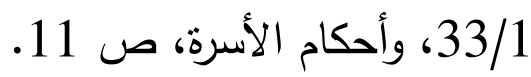

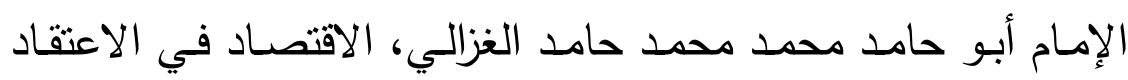

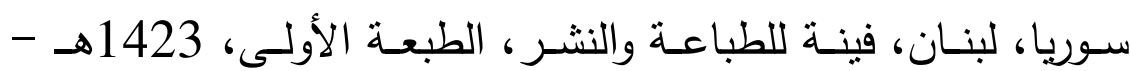

$$
\text { 2003 }
$$

الإمام عبد الملك بن عبد الله بن يوسف محمد الجويني، الإرشاد، ص

أبو الفتح محمد بن الكريم بن أحمد الثهرستاني 479-548، نهاية

الأقدام في علم الكلام، مكتبة المصطفى الوقفية، ص 559.

$$
\text { (36) ابن تيمية، منهاج السنة، 70/1 7) }
$$

(37) د. يوسف القرضـاوي من فقه الدولة في الإسـام، دار الثنروق، ط4،

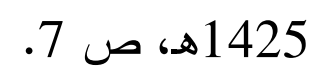

(38) محمد سليم العوا، الفقه الإسـلامي في طريق التجديد، القاهرة، سفير

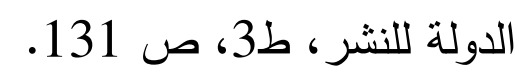

د. يوسف القرضاوي، نحو فقه ميسر ، ص 11 11، 12.

(40) محمد بـن الحسن الحجوي الفاسـي، الفكر السـامي في تـاريخ الفقـهـ

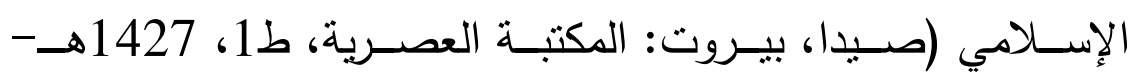

$$
\begin{aligned}
& \text { 2006م، ج1، ص } 23 .
\end{aligned}
$$

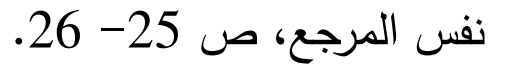

$$
\begin{aligned}
& \text { (42) الفكر الإسلامي، مرجع سابق. }
\end{aligned}
$$

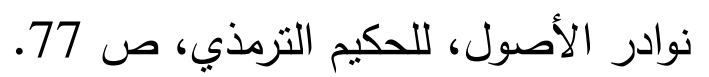


(44) مدخل الثريعة، عبدالكريم زيدان، ص 53.

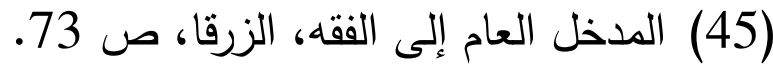

(46) عبد الكريم زيدان، المدخل لدراسة الثريعة، ص 155.

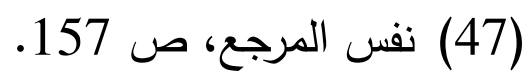

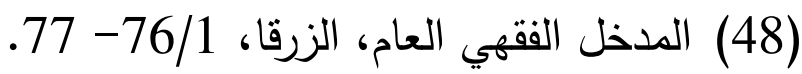
(49) الفكر السامي، 50/1.

(50) أحمد أمين، فجر الإسـلام، صيدا، بيروت، المكتبـة العصرية، ط1، المب،

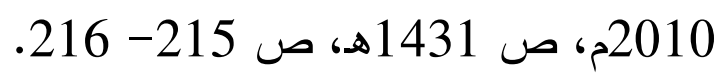

د. دحمد حسن هيتو، الوجيز في أصول التشريع الإسـامي، سوريا،

بيروت، مؤسسة الرسالة، ط2، 1405هـ- 1984م، ص 331.

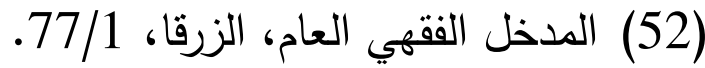

(53) المدخل لدراسة الثريعة، زيدان، ص 165.

(54) الفكر السامي، مرجع سابق، ص لـ 69 (5)

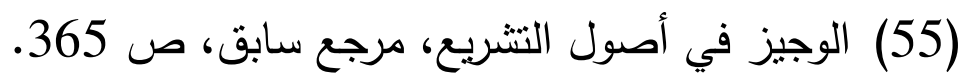

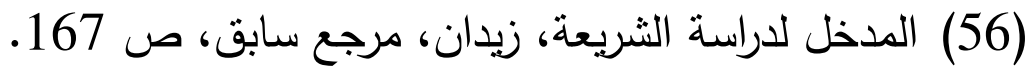

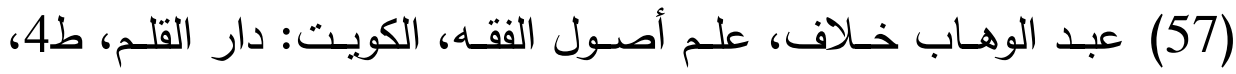

$$
\text { 1401هـ- 1981م، ص صد } 52
$$

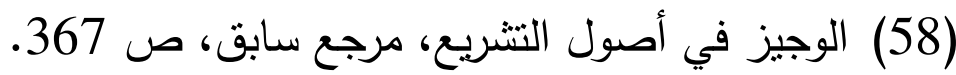

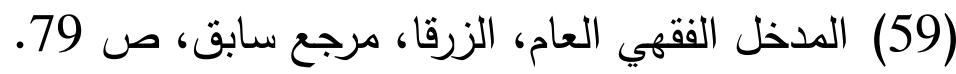

(60) أبو الفتح محمد بن عبد الكريم الثهرستاني، الملل والنحل، 1/ 1 / 205.

(61) الوجيز في التشريع الإسلامي، مرجع سابق، ص 439 (62)

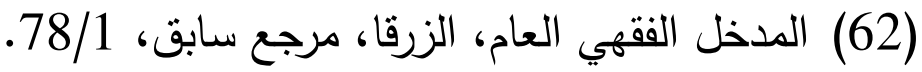


(63) المدخل لدراسة الثريعة الإسلامية، زيدان، ص 172. (64) علم أصول الفقه، خلاف، ص 84. (65) محمد علي السايس، تاريخ الفقه الإسـامي، بيروت، لبنان، دار الفكر

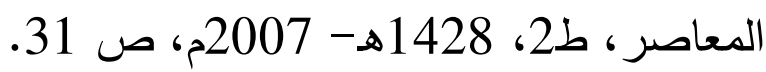

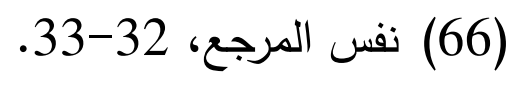

(67) الفقه الإسلامي وأدلته، الزحيلي، 32/1)

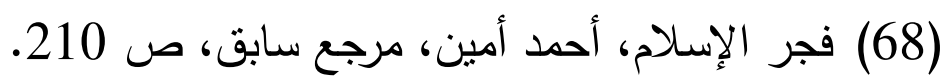

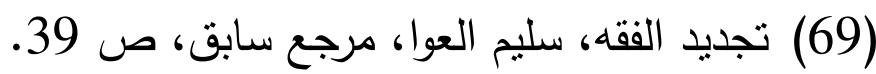

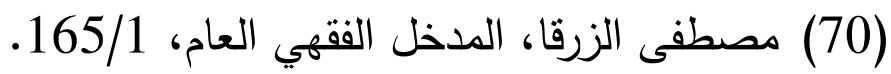

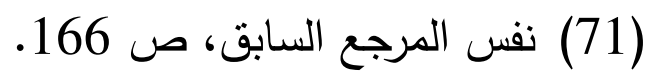
(72) الموسوعة الفقهية الكويتية، ص 23. (73) مدخل لدراسة الثريعة، مرجع سابق، ص صد 99.

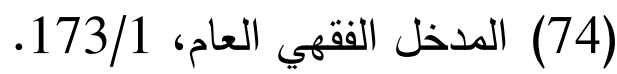
(75) فجر الإسلام، مرجع سابق، ص 216.

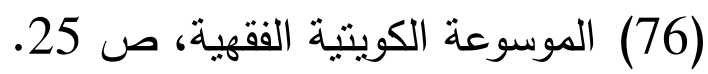

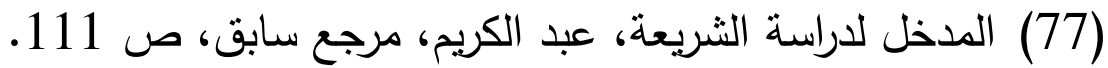
(78) المدخل الفقهي العام، الزرقا، مرجع سابق، 185/1.

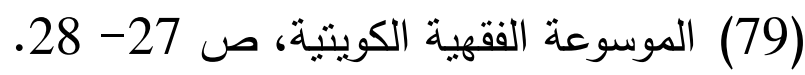
(80) الدذخل الفقهي العام، الزرقا، مرجع سابق، 200/1.

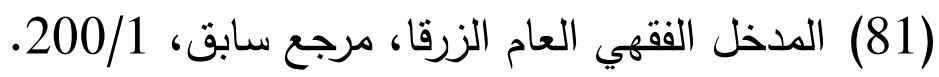
(82) المدخل لدراسة الثريعة الإسلامية، مرجع سابق، 118. (83) الفقه الإسلامي وأدلته، مرجع سابق، 43/1. 
(84) الموسوعة الفقهية الكويتية، 32/1.

(85) المدخل لدراسة الثريعة، مرجع سابق، صع الثه 122.

(86) الدخل الفقهي العام، الزرقا، مرجع سابق، 203/1.

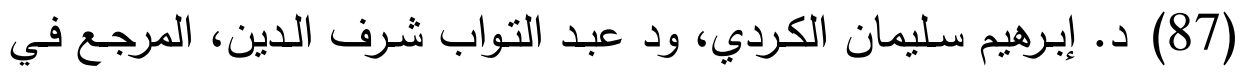

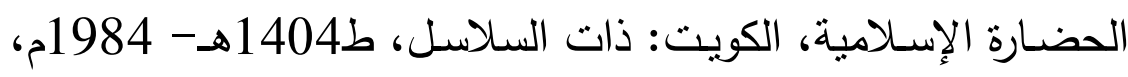

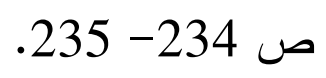

(88) ابن منظور ، لسان العرب، 111/3.

(89) الفقه الإسلامي للقرضاوي، مرجع سابق، ص 29-30-30.

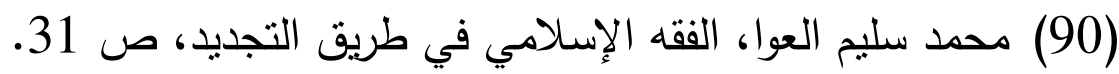

(91) أبو داؤد، السنة كتاب الملاحم، حديث رقم (4270).

(92) بسطامي محمد سعيد، مفهوم التجديد، ط1، صاب، صل 3.

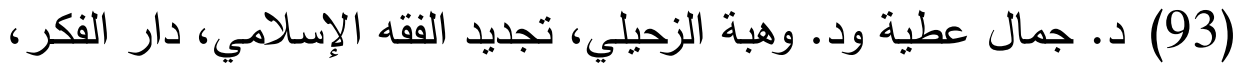

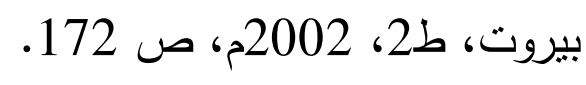

. 19 (94) نفسه صل 19$)$

(95) حليمـة بوكروشـة، معـالم تجديد المنهج الفقهي - أنموذج الثـوكاني،

قطر، وزارة الأوقاف، ط1، 1413هـ، 2002م، ص 182.

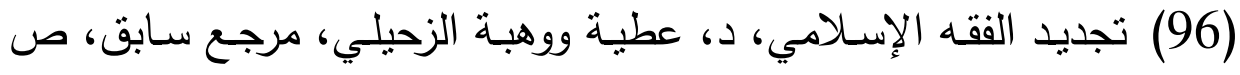

.173

(97) تجديد الفقه الإسـلامي، د، عطية ووهبـة الزحيلي، مرجع سـابق، ص

.177

(98) الفقه الإسـلامي في طريق التجديد، سليم العوام، مرجـع سـابق، ص 
(99) فقه الدولة، القرضاوي، ص 7.

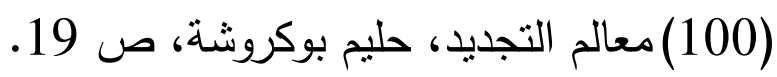

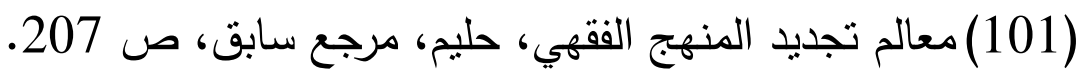

(102) نفسه ص 207-208)

(103) البيعة فقهاً وممارسة رسالة دكتوراه، التوم محمد المشرق، ص 102 صـ

.40

(104) البيعة فقهاً وممارسة رسالة دكتوراه، التوم محمد المشرق، ص 10-

.40

(105)د. يوسـف القرضــاوي، مـن أجـل صـحوة راشــدة، بيـروت، المكتب

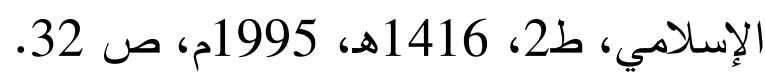

